\title{
Sławomir Karp
}

https:// orcid.org/0000-0002-6822-4831

Podkowa Leśna

\section{W cieniu długów, sąsiedzkich sporów, zajazdów i procesów. Obraz Chryzostoma Karpia (1650-1714), posesjonata $\mathrm{z}$ powiatu słonimskiego}

Zarys treści

W artykule przedstawiono postać Chryzostoma Karpia, posesjonata z powiatu słonimskiego. Prezentując jego losy, autor pragnie zwrócić uwagę na specyfikę postaw szlachty tego powiatu na przełomie XVII i XVIII w.

\begin{abstract}
The article presents the figure of Chryzostom Karp - a rich landowner from the Slonim County. Presenting the life of Chryzostom, the author would like to draw attention to the specificity of the attitudes of the Slonim County nobility at the turn of the eighteenth century.
\end{abstract}

Słowa kluczowe: Karpiowie, Luszniew, powiat słonimski w XVII i XVIII w.

Keywords: Karp family, Luszniew, Slonim County in the seventeenth and eighteenth centuries

Chryzostom Karp herbu własnego urodził się w 1650 r. w zamożnej rodzinie szlacheckiej, jako najstarszy z siedmiorga dzieci ${ }^{1}$. Jego przodkowie po mieczu już od początku XVI w. mocno trzymali się na Podlasiu, Grodzieńszczyźnie, a zwłaszcza ziemi wołkowyskiej². Z kolei krewni ze starszej linii, tzw. rykijowskiej,

${ }^{1}$ Miał trzech braci: Teodora Leona, podstolego podlaskiego, Krzysztofa Ubalda i przyrodniego Stanisława Antoniego oraz trzy siostry: Barbarę z Karpiów Stanisławową Teofilową Dobrosołowską, Krystynę z Karpiów Aleksandrową Felicjanową Cieszkowską, chorążynę Nowogródka Siewierskiego, starościnę kleszczelską (Cieszkowski pod koniec życia otrzymał od Augusta II kasztelanię czernihowską, ale jej nie zaprzysiągł i umarł bezpotomnie w 1708 r.) oraz najmłodszą, przyrodnią Konstancję z Karpiów Aleksandrową Rusiecką, kasztelanicową mińską.

2 Pradziad Józef i stryj Stefan byli marszałkami wołkowyskimi; zob. S. Karp, Józef Karp (ok. 1567-1637), marszałek wołkowyski - rys biograficzny, „Studia Podlaskie” 24, 2016, s. 12-14; idem, Gałaź 
systematycznie zasiedlali Żmudź, Auksztotę, a nawet od lat 30. XVII w. Kurlandię. Ojciec Józef Eliasz Karp (1630-1687), podkomorzy ziemi bielskiej, pułkownik JKM i półpanek podlasko-grodzieński, był elektorem i wiernym stronnikiem Jana II Kazimierza ${ }^{3}$. Matka Elżbieta (Halszka) Cecylia Sapieżanka była córką Mikołaja, kasztelana wileńskiego, pana na Kodniu. Wujowie to Kazimierz Melchiades (ok. 1625-10 I 1654), starosta krzepicki i Jan Ferdynand (1629-27 III 1659), cześnik litewski, starosta mołczadzki, Sapiehowie.

Chryzostom Karp, podkomorzyc ziemi bielskiej, całe życie spędził w Wielkim Księstwie Litewskim. Tu się urodził, wychowywał, edukował, dorastał ${ }^{4}$ i odziedziczył majątki ${ }^{5}$. Prowadził interesy, nawiązywał relacje sąsiedzkie, ożenił się, odbywał służbę wojskową oraz uczestniczył w życiu społecznym, gospodarczym i politycznym. Reprezentując zasiedziałą wyższą warstwę szlachecką, o dobrym ustosunkowaniu lokalnym - w co najmniej trzech powiatach Wielkiego Księstwa (grodzieńskim, wołkowyskim, słonimskim) - daje nam możliwość prześledzenia i oceny kolei losów przedstawiciela tej warstwy społecznej drugiej połowy XVII w. Wydaje się, że ukazany poniżej obraz szlachcica jest reprezentatywny dla ówczesnego powiatu słonimskiego. Zarysowane tu postawy ziemiańskie Jacyniczów, Szyszków i Wołk-Łaniewskich zdają się to potwierdzać i raczej nie napawają optymizmem.

Wiemy, że w 1661 r., mając 11 lat, Chryzostom „śmiertelnie zachorzał”. Szczęśliwie młody organizm wygrał $\mathrm{z}$ chorobą. Uzdrowienie dziecka matka przypisała cudowi boskiemu, co zostało odnotowane w kronikach klasztoru w Różanymstoku6. Przekaz podaje: „[matka] utwierdzona w wierze, nic już nie wątpiąc o cudach Obrazu Różano-Stockiego ${ }^{7}$, tamże go [Chryzostoma] ofiarowała y wraz pocieszona została, kiedy za powstaniem z gorączki zdrowego syna oglądała". Niedługo później oboje, chcąc podziękować opatrzności Bożej, przybyli do Różanegostoku i przysięgą swoją cud ten potwierdzili.

Następna wzmianka o naszym bohaterze pochodzi z 13 grudnia $1672 \mathrm{r}$. Wtedy to w Brańsku 22-letni Karp został posłem ziemi bielskiej na sejm pacyfikacyjny9. Obrady trwały od 4 stycznia do 11 marca 1673 r. w Warszawie i choć Chryzostom został wymieniony wśród parlamentarzystów z Małopolski, nie mamy pewności

rodziny Karpiów na Repli i Żłobowszczyźnie w XVII w. Studium genealogiczno-majątkowe, „Studia Podlaskie" 27, 2019, s. 25-60. Jeszcze pod koniec XVI w. tamtejszym podkomorzym został Mikołaj Iwanowicz Karp, starościc i sam starosta nowodworski, rodzony brat marszałka Józefa.

3 Józef Eliasz Karp był wychowankiem dworu Wazów. Urząd podkomorzego (6 V 1658 r.) i stopień wojskowy otrzymał za zasługi dla Rzeczypospolitej w okresie Potopu szwedzkiego.

${ }^{4}$ Główną siedzibą ojca była Brzostowica Murowana na Grodzieńszczyźnie.

${ }^{5}$ Posażny kompleks ziemski matki w powiecie słonimskim.

${ }^{6}$ Obecnie pow. sokólski.

${ }^{7} \mathrm{Na}$ krótko przed tym podkomorzowie stracili młodszego syna Antoniego.

${ }^{8}$ G. Jurkowski, Wonność mistycznej róży, Wilno 1762, pkt. 2.

9 Archiwum Narodowe w Krakowie, Zbiór Zygmunta Glogera, sygn. 16, s. 176. 
czy faktycznie wziął w nich udział ${ }^{10}$. Jak widać, ojciec dość szybko wprowadzał go w arkana życia politycznego. Początkowo też celem usamodzielnienia gospodarczego przekazał mu majątek Golnie z wsią Kordziki w powiecie grodzieńskim. Był to spory folwark odłączony specjalnie dla niego od głównej rodzicielskiej siedziby - Brzostowicy Murowanej. Notabene dostał też kilka części różnych matczynych majętności w powiecie słonimskim. Tam jednak gospodarowanie rozpoczął od zastawów i konfliktów. 5 października 1679 r. przed sądem ziemskim słonimskim skarżyła go Elżbieta Radoszewska, starsza konwentu benedyktynek słonimskich. Powodem skargi było uchylanie się od przyznania wyderkafu zastawnego na dobra Serebryszcze. Kontrakt opiewał na 5 tys. $z^{11}$. Przy czym był to dopiero początek długotrwałego sporu sądowego, który niedługo potem z wokandy powiatowej trafił do Trybunału Głównego Litewskiego. Kolejna rozprawa odbyła się 5 sierpnia $1685 \mathrm{r}$. Tym razem toczyła się z powództwa Konstancji Sołtanówny, starszej zakonu benedyktynek konwentu słonimskiego. Aktywnie wspierał ją patron Samuel Koreywa. Nieco wcześniej, tj. 19 maja, woźny Jakub Franciszek Sawicki przeprowadził stosowną wizję lokalną. Potwierdziła ona straty zakonnic. Poza nieustąpieniem majątku chodziło tu także o zaległość 36,5 beczki zboża (17 beczek żyta po 18 zl, jarskie zboża - beczek 4 po 72 zł, gryki 6 po 16 zł, owsa 9 po 8 zł, pszenicy pół beczki za 12 zł). Oprócz „pochwałek na zdrowie i życie" benedyktynki wyceniły szkody w ruchomościach na 558 zł. Wspólnie jednak z długiem na Serebryszczach całość obciążeń finansowych Chryzostoma zgodnie z wyrokiem sądu - wyniosła sporą sumę $11246 \mathrm{zl}^{12}$.

Wiemy, że już wtedy (1685 r.) Karp był żonaty. Wybranką była Anna Katarzyna Ciechanowiecka h. Dąbrowa (ur. 1656 lub 1657 r.), podkomorzanka mścisławska, córka Samuela Kazimierza ${ }^{13}$ i jego drugiej żony, Katarzyny Dunin Rajeckiej, wojewodzianki mińskiej. Karpiowie szybko doczekali się syna Józefa. Informacja

${ }^{10}$ Szerzej o instrukcji poselskiej szlachty bielskiej zob. L.A. Wierzbicki, O zgodę w Rzeczypospolitej. Zjazd warszawski i sejm pacyfikacyjny 1673 roku, Lublin 2005, s. 293; Z. Hundert, Konfederacja szczebrzeszyńska 1672-1673 a ziemia bielska, „Przegląd Historyczny” 107, 2016, nr 2, s. 242-243.

11 Pozew wręczył Jan Antonowicz, generał JKM powiatu słonimskiego, w asyście Jana i Pawła Żabickich; zob. NGAB, f. 1755, inw. 1, nr 44, k. 567.

12 LVIA, SA 347, k. 693-694v.

13 Samuel Kazimierz Ciechanowiecki (ok. 1625-15 II 1699) to postać majętna i bardzo aktywna. Jego biogram zob. Dzieje rodziny Ciechanowieckich herbu Dąbrowa (XIV-XXI), red. A. Rachuba, oprac., H. Lulewicz, A. Rachuba, J. Sikorska-Kulesza, S. Dumin, A. Haratym, A. Macuk. A. Pospiszil, Warszawa 2013, s. 103-111. Należy sprostować błąd występujący w: T. Żychliński, Złota księga szlachty polskiej, t. 13, Poznań 1891, s. 38, na podstawie mylnego przekazu Bronisława Bouffałła, jakoby Anna Karpiówna była żoną Samuela Kazimierza Ciechanowieckiego. Miał się on udać do Moskwy po wzięciu jej w niewolę „przy oblężeniu Bychowca” w 1654 r. W rzeczywistości była jego córką. Błędna jest też informacja, że Samuel i Anna z Karpiów Ciechanowieccy ok. 1676 r. w Packowie w starostwie czerykowskim ufundowali klasztor Dominikanów; zob. Słownik geograficzny Królestwa Polskiego i innych krajów słowiańskich, t. 7, red. B. Chlebowski, W. Walewski, F. Sulimierski, Warszawa 1886, s. 809. 
występująca w niektórych opracowaniach (np. w Złotej księdze szlachty polskiej Teodora Żychlińskiego), jakoby ich drugim potomkiem był cysters Andrzej Karp jest błędna ${ }^{14}$. Niestety małżeństwo to długo nie przetrwało, Ciechanowiecka bowiem na przełomie 1685 i 1686 r. mocno podupadła na zdrowiu. 3 stycznia 1686 r. w Golniach, „obłożną chorobą nawiedzona”, spisała testament. Stan faktycznie musiał być bardzo poważny, skoro do aktykacji ostatniej woli doszło 12 marca w sądzie grodzkim grodzieńskim ${ }^{15}$. Pochówku dokonano „w kościele ejsymontowskim, przy cudownym obrazie Panny Przenajświętszej [jedynie] w koszuli tkackiej”. Poza tym zmarła zaleciła w ostatniej woli, ,,aby trumna niczym nie obita była, jeno czarno pomalowana, a krzyż biały na wierzchu". Testatorka przekazała na kościół w Ejsymontowie dawny ojcowski oblig na 3500 zł. Był on wystawiony przez Jerzego Zygmunta i Eufrozynę z Mleczków Rajeckich, marszałków wiłkomierskich, i dany Ciechanowieckiemu „na on czas stolnikowi smoleńskiemu"16. Ponieważ ten trudno ściągalny zapis stanowił część jej posagu ${ }^{17}$, możemy uznać, że Chryzostom Karp wziął pannę z miłości i upodobania, a nie ze względów materialnych. Nie dziwi też, że jeden z głównych spadkobierców, proboszcz Długoborski sam fatygował się do Grodna, aby nadać bieg sprawie. W zamian miał odprawiać dwie msze tygodniowo za duszę spadkodawczyni i jej dziatek. Pierwsza „w poniedziałek śpiewana a [druga] we czwartek czytana u wielkiego ołtarza”. Karpiowa wskazała także, aby odzyskane środki ulokować na jakimś folwarku, by przynosiły „pewny procent i aby księża proboszczowie na swój pożytek nie obracali”. Na pogrzeb przeznaczyła 500 zł. Natomiast przywianek w kwocie 26 tys. zł, zabezpieczony przez męża na Golniach i Kordzikach, w połowie przeznaczyła właśnie jemu, a drugą połowę synowi. Z kolei przetrzymywane przez starego Ciechanowieckiego należne jej po matce klejnoty zapisała pierworodnemu Józefowi. Scedowała mu także inny niewypłacony dotąd oblig ojcowski na sumę 3 tys. zł. Kolejne dwa obligi, tj. na 10 tys. zł pana Winka i drugi na 3 tys. zł Wilhelma Witena, chorążego wendeńskiego, otrzymane w ramach posagu, miały być oddane ojcu i wypłacone gotówką, którą po równo chciała obdzielić męża i syna. Pozostałych przypadających jej wierzytelności, tak jak po zmarłym Jerzym Tyzenhauzie, mieczniku Wielkiego Księstwa Litewskiego ${ }^{18}$, Chryzostom Karp miał dochodzić osobiście ${ }^{19}$. Wiemy, że Samuel Kazimierz Ciechanowiecki

\footnotetext{
${ }^{14}$ Nie pochodził on z tej odnogi rodziny Karpiów.

15 Formalności dopełnił Łukasz Długoborski, proboszcz ejsymontowski.

16 Był nim najprawdopodobniej od stycznia 1656 r. Natomiast 23 V 1678 r. tytułował się podkomorzym mścisławskim; zob. Dzieje rodziny Ciechanowieckich herbu Dąbrowa..., s. 103-104.

17 NGAB, f. 1711, inw. 1, nr 1, k. 293v-294.

18 Zm. 6/7 IX 1679 r.

19 NGAB, f. 1711, inw. 1, nr 1, k. 292-294v. Pieczętarzami testamentu byli: Samuel Bisping, pisarz ziemski starodubowski, Andrzej Strzałkowski, skarbnik brasławski i Marcjan Kazimierz Ejsymont, podstoli starodubowski.
} 
nie tylko poskąpił jedynaczce na posag, ale też nie zadbał o wnuka. Finansowo wspierał wyłącznie swoich bratanków, najpewniej mając na uwadze głównie dobro własnego rodu. Zresztą podobnie rzecz się miała $\mathrm{z}$ wypłaceniem posagów siostrom Herakli i Marcjannie Ciechanowieckim. W obu przypadkach doprowadził on do ostrego sporu sądowego ze szwagrami. Natomiast Chryzostom Karp nigdy nie wszczął z nim procesu o należne środki materialne. Prawdopodobnie nie przywiązywał do nich większej wagi. Poza tym niedługo później zmarł - nie osiągając lat sprawnych - ukochany syn Józef, ewentualny pretendent do niniejszej spuścizny.

Wkrótce po tej dotkliwej stracie Karp ponownie wpadł w wir procesów sądowych. Już 15 i 22 czerwca oraz 7 sierpnia 1686 r. w Wilnie przed Trybunałem Głównym procesował się z Rafałem i Justyną z Jeleńskich Jankowskimi. Tym razem Karp mocno lawirował, nie chcąc zwrócić im pożyczonych $200 \mathrm{zł}$. Z uwagi jednak, że na części rozpraw w ogóle się nie pojawił, w rezultacie skazano go na banicję procesową i zapłacenie 300 zł (w tym 100 zł kosztów sądowych) ${ }^{20}$.

Jak widzieliśmy, Chryzostom najpierw gospodarował w Golniach i Kordzikach. Później na mocy ostatniej woli ojca, spisanej 22 maja 1687 r. w Brzostowicy Murowanej, otrzymał Luszniew w powiecie słonimskim i Nowy Dwór w powiecie grodzieńskim. Niestety obie majętności były dość mocno zadłużone. Zgodnie z wytycznymi ojca oraz chcąc mieć ziemię skomasowaną w jednej okolicy, oddał braciom dotychczasową posiadłość, a przejął wszystkie rodzinne włości w powiecie słonimskim. Był to obszerny kompleks ziemski po Sapiehach. W jego skład wchodził: Luszniew (folwark Haniewo, wsie Luszniew, Zamościany, Zwierowszczyzna), Serebryszcze (wieś Błoszna), Wysock (wieś Wiszowa), Iwankowicze (wieś i folwark Pierzchowicze, wieś Skorodyńce, folwark Łotwicze alias Sierki), Dukrów, Plechów. Dość szybko okazało się, że i one były obciążone różnymi braterskimi długami. Trzeba jednak podkreślić, że nowy właściciel dobrze znał propozycję i zamiary ojca w kwestiach spadkowych. Był bowiem jednym ze świadków podczas sporządzania testamentu ${ }^{21}$. Chodziło mu zaś o skupienie tych majętności w jednym ręku przez osobę mieszkającą na miejscu, a nie o gospodarowanie na odległość, jak to wcześniej w rodzinie praktykowano. Oprócz tego zgodnie z zapisami testamentowymi miał on rocznie płacić „na Lampę do Nayświętszey Panny Żurowickiey ${ }^{22} 100$ zł z Luszniewa”. Otrzymał też 1/5 ojcowskich stad bydła i koni z Brzostowicy Murowanej i Drewnianej ${ }^{23}$.

${ }^{20}$ LVIA, SA 349, k. 829-830v, 1990-1991v. 6 maja tegoż roku w Golniach Samuel Łuckiewicz, generał grodzieński, złożył pozew Karpiowi. Na procesie Jankowskich reprezentował Jerzy Wojtkiewicz (Woytkowicz), natomiast w sierpniu ich patronem był Samuel Koreywa. Pozew łącznie z obwieszczeniem wyroku na 300 zł i wypis z 1 lipca przedstawił w Golniach Teodor Drozdowicz, generał grodzieński.

${ }^{21}$ LVIA, SA 14805, k. 1615-1615v.

22 Żyrowicze, pow. słonimski.

${ }^{23}$ LVIA, SA 14805, k. 1611v, 1614. 
15 marca 1688 r. w Grodnie Chryzostom miał kolejny proces z benedyktynkami o Serebryszcze. Utrzymano tam wyrok Trybunału Głównego kadencji wileńskiej z 9 sierpnia 1685 r., nakazujący zapłatę 11246 zł na rzecz zakonnic. Widać, że Karp stale „grał na czas”, natychmiast bowiem wniósł apelację i czekał na rozwój wydarzeń ${ }^{24}$. Tym razem jednak dość szybko został przyparty do muru i już 23 kwietnia 1688 r. w Serebryszczach oddał im w trzyletni (1688-1691) zastaw Iwankowicze Małe w powiecie słonimskim. Transakcję opiewającą na 5500 zł sfinalizowała starsza zakonu Konstancja Teofila Przysiecka i przeorysza Scholastyka Drobyszówna. W skład zastawionej majętności oprócz iwankowickiego centrum dworskiego wchodziły wsie Skorodyńce i Pierzchowicze ${ }^{25}$. Z kontraktu Karp wyłączył mieszkającego w Skorodyńcach Pawluka Narbuta z synami, a w jego miejsce oddał „Jaroszową Strycharzową z synami na Zamościu w Luszniewie mieszkającą". Z innych dokumentów wiadomo, że był to zaufany człowiek Karpia, dobry strzelec i wytrawny myśliwy. Nie dziwi więc, że dziedzic chciał go mieć przy sobie. Dodatkowo Karp zezwolił benedyktynkom na „wolne mliwo” w młynie w Wysocku oraz „wolny wjazd do puszczy luszniewskiej na potrzebę klasztorną" ${ }^{26}$. Oprócz tego strony zawarły drugi kontrakt. Na jego mocy podkomorzyc odstąpił benedyktynkom za 4 tys. zł odłączoną od Serebryszcz wieś Błoszną. Trzyletnią umowę podpisały zakonnice Konstancja Teofila Przysiecka i Krystyna Jacynianka. Ponadto wypłacił im 500 zł w ramach wszystkich kosztów poniesionych od $1684 \mathrm{r}^{27} \mathrm{~W}$ tej sytuacji 7 maja $1688 \mathrm{r}$. w Serebryszczach starsza konwentu Konstancja Teofila Przysiecka i przeorysza Scholastyka Drobyszówna $\mathrm{w}$ imieniu sióstr klasztoru słonimskiego skwitowały Karpia z wszelkich pretensji. Trzeba zaznaczyć, że do powyższego konsensu doszło po negocjacjach

${ }^{24}$ LVIA, f. 389, ap. 1, nr 382, cz. 8, k. 415-418v, k. 420-421v.

25 Dokument aktykowano 6 X 1688 r. W późniejszym czasie syn Chryzostoma, Jan Karp, opłacił z Pierzchowicz podatek z 7 i 1/2 dymów; zob. Metryka Litewska. Rejestry podymnego Wielkiego Księstwa Litewskiego. Województwo nowogrodzkie 1690 r., red. A. Rachuba, oprac. H. Lulewicz, A. Rachuba, Warszawa 2002 (dalej: ML. Podymne nowogrodzkie 1690), s. 16.

${ }^{26}$ NGAB, f. 1785, inw. 1, nr 45, k. 921-922v, 931-932v. Pieczętarzami trzyletniego zastawu byli: Ignacy Przysiecki, podstoli połocki i starosta koziański, Kazimierz Przecławski, starosta bialski oraz Mikołaj Kazimierz Zawadzki i Mikołaj Gumowski. Z inwentarza majątku dowiadujemy się o dobrym stanie budynków, należycie obsianych polach oraz o 11 gospodarzach uprawiających 4 i 3\%/4 włóki we wsi Pierzchowiczach, 3 poddanych żyjących na 1 włóce w Luszniewie i 2 utrzymujących się z 1 włóki; zob. ibidem, k. 919-920v, 937-938v.

27 Ibidem, k. 917-918v, 929-930v. Akt sygnowali: Kazimierz Przecławski, starosta bialski, Mikołaj Kazimierz Zawadzki i Mikołaj Gumowski. W inwentarzu Błosznej wyszczególniono 4 i 1⁄2 włóki ciahłe, 3 włóki czynszowe i 2 puste. Mieszkało tam 11 gospodarzy mających 23 synów, 5 koni, 10 wołów i 5 krów. Robocizna dla mężczyzn wynosiła 3 dni w tygodniu z synem przez lato i zimę. Płacili oni z ciahłej włóki 20 groszy, a z czynszowej 3 kopy groszy. Natomiast podarki do dworu odprowadzali następujące: z włóki - beczka żyta, beczka owsa, gęś, dwie kury, jajek 20; zob. ibidem, k. 927-928v, 935-936v. 
prowadzonych od 7 marca 1688 r. Najpewniej wcale by go nie osiągnięto, gdyby dziedzic nie został do tego przymuszony w 1685 r. przez Trybunał kadencji wileńskiej, a następnie 15 marca $1688 \mathrm{r}$. przez sąd asesorski. W tym ostatnim został skazany na wieczną banicję ${ }^{28}$. Ostatecznie winowajca spłacił zakonnice dopiero w $1694 \mathrm{r}$. i to po wielu jeszcze procesach sądowych ${ }^{29}$. O wielkości zastawionych dóbr zaświadcza abiurata z 1690 r. Dowiadujemy się z niej, że Konstancja Teofila Przysiecka, starsza benedyktynek konwentu słonimskiego, opłaciła z Iwankowicz Mniejszych i zastawnej wsi Błosznej podatek za 3 dymy. Natomiast Klara Wołłowiczówna, starsza konwentu słonimskiego św. Franciszka $-\mathrm{z}$ areału luszniewskiego, młyna i karczmy uregulowała należność za 16 dymów $^{30}$. Poza tym za zastawny 1 dym w Wysocku oraz 1 dym z Błosznej podatek zapłacił Marcin Piotrowicz, protopop słonimski ${ }^{31}$. Z kolei z zastawionego Dukrowa taksę wniósł Jerzy Wołłowicz, podkomorzyc słonimski, syn Anny Izabeli Karpiówny, krewnej z gałęzi na Repli i Żłobowszczyźnie. Opłacił on podatek za 2 dymy, a w tym za tamtejszą karczmę oraz dwór w Słonimie ${ }^{32}$. Innym zastawnikiem Karpia w tej wsi był Aleksander Kuncewicz, który w 1690 r. opłacił należność z 1 dymu ${ }^{33}$. Nieco wcześniej, 5 kwietnia 1688 r., w Serebryszczach Chryzostom Karp zrzekł się folwarku Haniewicze (Haniewo) na rzecz Mikołaja Kazimierza i Anny z Kopowskich Zawadzkich. Grunty te niegdyś należały do Luszniewa, a Zawadzcy mieli na nich zabezpieczone dożywocie $\mathrm{w}$ wysokości 1 tys. zł jeszcze przez podkomorzego Karpia. Tymczasem Chryzostom postanowił odwdzięczyć się za ich wieloletnią służbę $\mathrm{i}$ „dobrowolnym zapisem transformować, z prawa dożywotniego w prawo wieczyste, [aby] onemu wzajemną moją dobroczynnością y do dalszej ochoty y życzliwości ku sobie pociągnąć”. Niestety Zawadzki „po zrujnowaniu nieprzyjacielskim moskiewskim pustkami objąwszy niemało kosztu na restaurację onej ważyć musiał"34. Najwyraźniej owa "transformacja” miała drugie dno. Nieustannie borykający się z brakiem gotówki Karp wolał wyzbyć się

${ }^{28}$ Ibidem, k. 923-926v. Świadkami porozumienia byli Benedykt Ignacy Przysiecki, podstoli połocki i starosta koziański, Kazimierz Przecławski, starosta bialski, Mikołaj Kazimierz Zawadzki i Mikołaj Gumowski.

${ }^{29}$ M. Borkowska OSB, Panny siostry w świecie sarmackim, Warszawa 2002, s. 50. Autorka myli się co do pierwszej osoby z rodziny Karpiów, która w 1679 r. zastawiła Serebryszcze. Niewątpliwie był nim Józef Eliasz, podkomorzy ziemi bielskiej, ojciec Chryzostoma.

${ }^{30}$ ML. Podymne nowogrodzkie 1690, s. 118.

31 Ibidem, s. 129. W tym czasie protopopem luszniewskim był Joachim Puzowski.

32 Po 1711 r. Dukrowo (1 dym) dalej pozostało niewykupione przez Chryzostoma; zob. ibidem, s. 139.

${ }^{33}$ Ibidem, s. 126. Nieco później całość wsi (8 dymów), tj. części Chryzostoma Karpia oraz jego zastawników Wołłowicza i Kuncewicza, dzierżyli Jakub i Róża z Wołłowiczów Kobylińscy, cześnikowie smoleńscy.

${ }^{34}$ NGAB, f. 1785, inw. 1, nr 45, k. 933-934v. Podpisali: Jan (!) Mikołaj Gumowski, Teodor Dadźbóg Rezan i Jan Michał Borkowski. Wypis wydano 10 IX 1762 r. 
zapuszczonych gruntów niż je zagospodarowywać. Była to kontynuacja uszczupleń dóbr, a tym samym przyszłych dochodów. Jak widać, zastał schedę słonimską znacznie zmniejszoną, ale i sam dzielił ją na potęgę między różnych nabywców. Swą donację potwierdził 6 października 1688 r. na rokach sądowych ziemskich słonimskich. Już następnego dnia przegrał tam sprawę z Piotrem i Marianną z Markiewiczów Kuroczyckimi, właścicielami Ciuchniewicz w powiecie słonimskim. Spór dotyczył dwóch poddanych z Iwankowicz, których wcześniej zastawił Kuroczyckim brat Teodor Leon Karp, podstoli podlaski ${ }^{35}$. Ich wartość oszacowano na 550 zł. Zaraz potem w tymże sądzie Chryzostom przegrał proces o Iwankowicze z Janem i Teresą z Jesmanów, chorążanką słonimską, Talwoszami Steckiewiczami, miecznikami oszmiańskimi. Karp chciał odzyskać majątek na mocy zapisu testamentowego ojca. Jednak w międzyczasie młodszy brat bardzo go zadłuży ${ }^{36}$. Nowo pobudowany folwark w Iwankowiczach Większych wraz z kilkunastoma poddanymi oraz młyn w Łotwiczach oddał w zastaw za 5220 zł. Jeszcze tego samego dnia (7 października) Chryzostom pozwał Stanisława ${ }^{37}$ i Zofię z Sołtanów, podkomorzankę starodubowską, Gadzałów, wojskich mozyrskich o zwrot włościanina z Pierzchowicz. Zastawił go za 200 zł ciągle poszukujący łatwego źródła finansowania Teodor Leon Karp. Szczęśliwie dla Chryzostoma tym razem sąd ziemski słonimski nakazał, by Gadzałowie oddali chłopa, a swoich roszczeń dochodzili na podstolim podlaskim. Wydaje się, że wygraną Karp zawdzięczał nieobecności Gadzałów na procesie ${ }^{38}$. Jednak najważniejszą sprawą tego dnia były rozliczenia braterskie. Zgodnie z pierwotnym podziałem ojcowskim Krzysztof Ubald Karp, podkomorzyc ziemi bielskiej, dysponował majątkiem Wysock i Iwankowicze Mniejsze. Z tego okresu i on pozostawił po sobie znaczne długi. Pierwszy zaciągnął u spowinowaconego Michała Wołłowicza, podkomorzego słonimskiego ${ }^{39}$ na $12 \mathrm{zł}$ (sic!) za poddanych z sioła Dukrowo ${ }^{40}$, a drugi na 250 zł u Michała Jacynicza, strażnika słonimskiego, za Awramka Slosara z sioła Wiszowa. Najpewniej był to właśnie ten zastaw wraz z gruntem, za który Jacynicz

35 Ibidem, k. 951-952v. Pełnomocnikiem Karpia był Piotr Korczyc, a Kuroczyckich - Krzysztof Żukowski.

36 Ibidem, k. 943-943v. Również na tym procesie Karpia reprezentował Piotr Korczyc, miecznik słonimski, a Steckiewicza - Krzysztof Żukowski. Funkcje woźnieńskie sprawował generał Jakub Franciszek Sawicki.

37 Właśc. Jerzy Gadzała Cypriakowski (Cyprykowski, Cypriakiewicz), wojski mozyrski. Za tę wskazówkę bardzo dziękuję prof. Andrzejowi Rachubie. Wynikałoby z tego, że nosił dwa imiona (Jerzy Stanisław).

38 Przebywali wtedy u Owsianego, stolnika mińskiego w dobrach Mołczadź w powiecie słonimskim. Pozew wręczył Jakub Franciszek Sawicki, generał JKM słonimski. Jak zwykle Karpia wspomagał na procesie umocowany Piotr Korczyc, miecznik słonimski; zob. NGAB, f. 1785, inw. 1, nr 45, k. 949-950v.

39 Mąż Anny Izabeli Karpiówny, marszałkówny wołkowyskiej z gałęzi na Repli i Żłobowszczyźnie.

${ }^{40}$ Wieś należała wtedy do dóbr Wysock. 
w 1690 r. opłacił podatek z 1 dymu ${ }^{41}$. Wyrokiem sądu ziemskiego słonimskiego Krzysztofowi Ubaldowi Karpiowi nakazano uregulowanie zaciągniętych zobowiązań. W tym miejscu należy pamiętać, że Chryzostom początkowo wziął Golnie w powiecie grodzieńskim, a później zamienił je z bratem na Wysock i Iwankowicze Mniejsze ${ }^{42}$. Podobnie rzecz się miała z Teodorem Leonem, od którego Chryzostom przejął Luszniew, Iwankowicze Mniejsze (zapewne pozostałą część), Iwankowicze Większe, Wysock (część) oraz Serebryszcze. Z nim także spotkał się w sądzie 7 października 1688 r. Tu z kolei w grę wchodziły, oprócz wcześniej wymienionych zobowiązań, długi wobec sióstr bernardynek ze Słonimia za trzech poddanych na sumę $500 \mathrm{zł} \mathrm{i} \mathrm{franciszkanek} \mathrm{słonimskich} \mathrm{za} \mathrm{wyderkaf} \mathrm{w} \mathrm{kwocie}$ 400 zł. Spór między braćmi nasilił się zwłaszcza po 15 maja tegoż roku. Teodor Leon nie tylko odmówił uregulowania własnych zobowiązań, ale, co niebywałe, zagroził bratu śmiercią i spaleniem jego majętności. Chryzostom widząc realną możliwość zrealizowania groźby, skierował skargę do sądu ziemskiego słonimskiego. Tradycyjnie w jego imieniu sprawę prowadził Piotr Korczyc, miecznik słonimski. Na procesie wskazał, że stary Karp w ostatniej woli wręcz nakazał synom płacić osobiste długi. W tej sytuacji sąd ziemski słonimski zobligował Teodora Leona do uregulowania zaciągniętych zobowiązań (2474 zł i 10 gr) i obciążył nimi Brzostowicę Drewnianą. Ta wygrana nie poprawiła znacząco sytuacji Chryzostoma. W dalszym ciągu utrzymano prawo zastawne Jana Talwosza Steckiewicza, miecznika oszmiańskiego, na Iwankowicze ${ }^{43}$. Był to bardzo atrakcyjny i niemały kawał gruntu. W 1690 r. Steckiewicz opłacił z niego podatek z 5 dymów ${ }^{44}$. Natomiast 8 marca 1689 r. podkomorzyc Chryzostom Karp miał sprawę z powództwa Jerzego (Stanisława) Gadzały Cypriakowskiego, wojskiego mozyrskiego, o dług w wysokości 802 zł. Suma ta także była zabezpieczona na Iwankowiczach. Szczęśliwie w międzyczasie doszło do pojednania między Karpiami i w tej sprawie za Chryzostoma zaręczył winowajca. Swoim wypróbowanym sposobem podstoli podlaski - najprawdopodobniej w porozumieniu $\mathrm{z}$ bratem - najechał dobra Cypriakowskiego, pobił go oraz poturbował kilku poddanych i okradł majętność. W rezultacie sprawa trafiła do sądu grodzkiego grodzieńskiego i zgodnie z wyrokiem nakazano agresorowi zadośćuczynić wyrządzonym szkodom. Dość hojnie wyceniono je na 33 tys. zł i $10 \mathrm{gr}^{45}$.

Niedługo potem, tj. w poniedziałek 25 kwietnia 1689 r., „,na rokach skarbowych grodzkich brańskich" Chryzostom Karp wspólnie z braćmi miał proces

\footnotetext{
${ }^{41}$ ML. Podymne nowogrodzkie 1690, s. 144.

${ }^{42}$ NGAB, f. 1785, inw. 1, nr 45, k. 947-948v. Krzysztof Ubald Karp nie stawił się na procesie, chociaż odebrał w Brzostowicy Murowanej wezwanie od woźnego - generała Jakuba Franciszka Sawickiego.

43 Ibidem, k. 939-942v.

${ }^{44}$ ML. Podymne nowogrodzkie 1690, s. 122.

${ }^{45}$ LVIA, f. 389, ap. 1, nr 505, k. 27-27v.
} 
o skasowanie kondemnaty na zapłacenie 1500 zł zaległego posagu po zmarłej siostrze Krystynie Karpiównie, żonie (Aleksandra) Felicjana Cieszkowskiego, podkomorzego czernihowskiego i starosty kleszczelskiego. Tym razem pozwanych braci reprezentował Krzysztof Ubald. Sporną sumę zapisał córce w testamencie podkomorzy Józef Eliasz Karp. Po jej rychłej śmierci kwotę scedowano karmelitom konwentu bielskiego i to właśnie oni upomnieli się o pieniądze. Pozew złożono we wtorek 3 maja w grodzie brańskim, a następnego dnia na konwencie bielskim $^{46}$. Na dodatek niedługo później, 8 lipca 1689 r. Chryzostom Karp wspólnie z braćmi toczył bój sądowy w Trybunale Głównym Wielkiego Księstwa Litewskiego z Markiem Butlerem, starostą drohickim i preńskim. Butler kontynuował proceder prawny o Zdzitowiec $\mathrm{w}$ województwie brzeskolitewskim, zaczęty jeszcze przez jego matkę Konstancję z Wodzińskich Butlerową, podkomorzynę koronną, z Józefem Eliaszem i Konstancją Dunin-Karwicką Karpiami, podkomorzymi bielskimi. Trwał on już co najmniej od 26 czerwca 1680 r. na kadencji wileńskiej. Kolejna rozprawa odbyła się 25 października tegoż roku w Nowogródku. Ponieważ wcześniej obciążono Butlera pokaźną karą, teraz postanowił on odwrócić bieg wydarzeń. Tak też się stało i to w dużej mierze ze względu na absencję braci Karpiów. Poprzedni niekorzystny dla Butlera wyrok z Nowogródka został unieważniony ${ }^{47}$. Niebawem, w 1689 r. „na roczkach trojeckich” w Słonimie Chryzostom Karp miał przyznać prawo zastawne na trzech poddanych Marcjanowi Piotrowiczowi, tamtejszemu protopopowi. Ponieważ zlekceważył on ten wymóg formalny, poszkodowany wraz z małżonką wniósł protest 18 stycznia $1690 \mathrm{r}^{48}$

Trzeba podkreślić, że jeszcze wtedy pomimo utraty części dóbr nasz bohater w dalszym ciągu dysponował znacznym majątkiem. W $1690 \mathrm{r}$. opłacił on z majętności Iwankowicze Większe, Serebryszcze i Wysock podatek z 40 dymów. Poza tym z Iwankowicz, Serebryszcza i Wysocka wniósł „abiuraty panien benedyktynek z dymów $1,1 / 6$ i 2/3"49.

Jeszcze 15 czerwca 1691 r. w ziemstwie słonimskim na Chryzostoma skargę złożyli Jerzy i Katarzyna z Szabrańskich Gadomscy z synem Franciszkiem. I tym razem Karp pomimo umowy zastawu na włókę gruntu $\mathrm{z}$ dwoma poddanymi unikał wywiązania się z niej ${ }^{50}$. Prawdopodobnie gromadził już wtedy fundusze na spłatę sióstr zakonnych. 24 czerwca 1692 r. w Serebryszczach Klara Wołłowiczówna, przeorysza z konwentu słonimskiego franciszkanek i Konstancja Sudowska, wikaria

\footnotetext{
${ }^{46}$ Pozew aktykował w Goniądzu Paweł Golecki, woźny generalny koronny; zob. NGAB, f. 1712, inw. 1, nr 3, k. 631-631v.

${ }^{47}$ LVIA, SA 356, k. 143-144v. Pozew 8 czerwca tegoż roku wręczył w Zdzitowcu generał Kazimierz Ostolski.

${ }^{48}$ NGAB, f. 1785, inw. 1, nr 46, k. 195-196v. 11 I 1690 r. potwierdził to Antoni Sawicz, generał JKM powiatu słonimskiego, wraz z Janem i Stanisławem Juchniewiczami.

49 ML. Podymne nowogrodzkie 1690, s. 119.

${ }^{50}$ NGAB, f. 1785, inw. 1, nr 46, k. 300-300v. „Pilność” do akt podał generał Antoni Sawicz.
} 
skwitowały go z odbioru 5 tys. zł zastawu, a także kwoty wyderkafowej nieopłaconej jeszcze od czasów panowania Teodora Leona. Zakonnice władały tym majątkiem od 3 września 1679 r. na mocy zastawu Józefa Eliasza Karpia, podkomorzego ziemi bielskiej. Najpewniej stosunki między zwaśnionymi stronami były już bardzo napięte, bo Chryzostom chcąc „pretensje zaspokoić został uglejtowany” przez króla $^{51}$. Dzięki temu odzyskał spory szmat ziemi. W 1690 r. Klara Wołłowiczówna z włości luszniewskiej, tamtejszej karczmy i młyna opłaciła podatek z 16 dymów ${ }^{52}$.

Rok 1696 przyniósł duże zmiany w życiu osobistym podkomorzyca. Ożenił się on $\mathrm{z}$ wdową Ewą Teresą Niewiarowską h. Półkozic, starościanką kadaryską i maćkowską primo voto Ferdynandową Janową Rorową (von Rohr) ${ }^{53}$, stolnikową trocką. Należy podkreślić, że pan młody liczył sobie już wówczas 46 lat, a jedynak Józef prawdopodobnie już nie żył. Natomiast wybranka miała z pierwszego małżeństwa trzech dorosłych synów (Tomasza, Aleksandra Kazimierza i Antoniego). Trzeba też przyznać, że dość mocno podreperowała Chryzostoma finansowo. Wniosła mu 12 tys. zł gotowizny, a na dodatek spłaciła długi zaciągnięte u panów Steckiewicza i Jacynicza. Był to pierwszy krok w oswobadzaniu majętności iwankowickiej. Później sukcesywnie odzyskiwała zastawionych chłopów. Zrezygnowała jedynie z Siemiona Matrunika, oddanego Janowi Narbutowi za 33 talary. Kwotę tę podkomorzycowie przeznaczyli na opłacenie podymnego z Iwankowicz oraz zapewne - tzw. stacji chorągwi starosty żmudzkiego Kazimierza Zaranka. Z tych pieniędzy zaradna Karpiowa uregulowała również wierzytelność Ignacego Tołokońskiego, horodniczego brasławskiego. Najpewniej jednak wszystkie te wydatki mocno nadszarpnęły rodzinną kiesę, bo już 24 czerwca 1697 r. w Nowym Dworze (pow. grodzieński) oboje "pilnie potrzebujący pieniędzy” puścili w zastaw tę majętność Aleksandrowi Kazimierzowi i Antoniemu Rorom, stolnikowiczom trockim. W transakcji wartej 28 tys. zł pośredniczył najstarszy z braci, Tomasz, ówczesny stolnik trocki ${ }^{54}$. Poza tym żyrował on sumę 10 tys. zł za Antoniego. Tę asekurację matka aktykowała 7 sierpnia 1698 r. w grodzie słonimskim ${ }^{55}$.

${ }^{51}$ Ibidem, k. 476-477v. W księgach ziemskich słonimskich aktykowano 3 X 1692 r. Pieczętarzami byli: Jan Kazimierz Talwosz Steckiewicz, miecznik oszmiański, Mikołaj Gumowski i Kazimierz Teofil Wojdag.

${ }^{52}$ ML. Podymne nowogrodzkie 1690, s. 118.

${ }^{53}$ Ferdynand Jan Pawłowicz Ror (von Rohr) herbu własnego, zm. między 26 XI 1692 a 29 IV 1693 r.

${ }^{54}$ NGAB, f. 1755, inw. 1, nr 56, k. 265-266v, 267-268v. 4 VIII 1706 r. do ksiąg grodzkich grodzieńskich aktykował Aleksander Kazimierz Ror, stolnik trocki. Natomiast ekstrakt dokumentu 18 X 1712 r. przed sądem ziemskim grodzieńskim złożył patron Mateusz Bylewski. Z zachowanego inwentarza gospodarczego (24 VI 1697 r.) dowiadujemy się, że w skład majątku wchodziły wsie: Nowosiółki (22 gospodarzy, 6 włók oraz łąki), Kubielniki ( 23 chłopów, 7,5 włóki oraz 6 łąk: Uroczyszcze Osielica, Pocierób, Studzienica, Werecieja Żabiszkinowszczyzna, piąta (nieczytelna) Hasai...(!) oraz na Wielkim Błocie, tzw. Błonie); zob. NGAB, f. 1711, inw. 1, nr 2, k. 146-147v; NGAB, f. 1755, inw. 1, nr 56, k. 223-224v.

55 RGADA, f. 356, inw. 1, nr 34, k. 63-66. Sygnowali: Samuel Bisping, sędzia ziemski starodubowski, Florian Władysław Machwic, łowczy grodzieński i Jan Siemkowski, podstoli starodubowski. 
Warto nadmienić, że jeszcze przed 10 lipca 1697 r. przyszedł na świat pierwszy syn małżeństwa Karpiów, Jan. Niestety jego przyszłość nie zapowiadała się zbyt optymistycznie. 23 kwietnia 1702 r. ojciec utracił kolejny majątek. Tego dnia szwagier Karpia, Gerwazy Wołk-Łaniewski, wojski mozyrski - żonaty z Konstancją z Niewiarowskich ${ }^{56}$, rodzoną siostrą Karpiowej - spłacił z Luszniewa bernardynki. Uregulował okrągłą kwotę 22 tys. zł i prawdopodobnie dokonał tego za plecami właściciela. Stąd, żeby go udobruchać, wypłacił mu dodatkowo 6 tys. zł. Tym samym przejął on karpiowski Luszniew ${ }^{57}$ za 28 tys. zt ${ }^{58}$. Już 24 czerwca 1702 r. Karp, jako nominalny właściciel, sam chciał uregulować zakonnicom sumę zastawną, ale one w umówionym terminie i miejscu się nie stawiły ${ }^{59}$. W rezultacie 5 sierpnia tego roku Dymitr Aleksandrowicz, generał JKM powiatu słonimskiego, wręczył im pozew w tej sprawie. Tymczasem również szwagier Wołk-Łaniewski odmówił przyjęcia pieniędzy i wydania majętności. Wobec tego Karp zaskarżył „wrogie” przejęcie do Trybunału Głównego Litewskiego i 18 października 1704 r. sąd ten skazał upartego zastawnika na infamię, jednocześnie nakazując mu odbiór pieniędzy od Karpia i wydanie majętności. Niestety, pomimo tego i dalszych korzystnych dla Chryzostoma wyroków kwestia zwrotu majątku przeciągnęła się aż do jego śmierci. Ponieważ osieroceni synowie w tym czasie byli jeszcze niepełnoletni, sprawa na dobre utknęła w martwym punkcie ${ }^{60}$.

$56 \mathrm{~W}$ innym dokumencie występuje z imieniem Anna.

57 W połowie XVII w. Jan Komorowski (zm. przed 10 VIII 1654 r.), podkomorzy wiłkomierski, biorąc od Józefa Eliasza Karpia (od 6 V 1658 r. podkomorzego ziemi bielskiej) w zastaw Luszniew, później odstąpił go bernardynkom ze Słonimia za sumę 22 tys. zł. Sapieżyńskie zadłużenie włości luszniewskiej 23 II 1668 r. wynosiło 70 tys. zł. Najpewniej dotyczyło ono nie tylko samego Luszniewa, lecz całego przejętego przez Karpia tamtejszego kompleksu ziemskiego, łącznie z Serebryszczami, Iwankowiczami, Pierzchowiczami, Wysockiem itd. Należy również zaznaczyć, że tylko jedna wzmianka spośród wielu podaje, że Komorowski wziął Luszniew bezpośrednio od Sapiehów; zob. LVIA, SA 14805, k. 1618.

${ }^{58}$ Dokument sprzedaży Luszniewa został aktykowany 27 II 1706 r. w grodzie nowogródzkim, a 3 VII 1710 r. przedłożono go Trybunałowi w Wilnie; zob. NGAB, f. 1785, inw. 1, nr 48, k. 503; LVIA, SA $14805, \mathrm{k} .1618 \mathrm{v}$.

${ }^{59}$ W 1690 r. z Luszniewa siostry zakonne opłaciły podatek z 16 dymów; zob. ML. Podymne nowogrodzkie 1690, s. 118.

60 Dopiero w 1726 r. w Trybunale na kadencji nowogródzkiej Wołk-Łaniewscy zostali „ostatecznie” zobowiązani do przyjęcia kwoty zastawnej i ustąpienia z Luszniewa. Jednak na niewiele się to zdało, strony ponownie bowiem spotkały się w Trybunale 10 VII 1727 r. w Wilnie. Tam również nie osiągnięto żadnego rozwiązania. Ignacy Wołk-Łaniewski, strażnik słonimski, chorąży petyhorski „znaku Księcia Jegomości Kasztelana Wileńskiego” (Kazimierz Czartoryski) po raz kolejny zlekceważył ferowane wyroki sądowe, a przede wszystkim prawo Jana i Franciszka Chryzostomowiczów Karpiów do spłaty zastawnika. Ponadto przeczy to informacji podanej przez R. Aftanazego, jakoby Wołłowiczowie byli właścicielami i budowniczymi dworu w Luszniewie już w XVII w.; zob. idem, Dzieje rezydencji na dawnych kresach Rzeczypospolitej, t. 2: Województwo brzesko-litewskie, nowogródzkie, Wrocław 1993, s. 247. W świetle moich ustaleń Wołk-Łaniewscy gospodarowali w Luszniewie jeszcze 19 X 1764 r.; zob. NGAB, f. 1785, inw. 1, nr 45, k. 536-536v. 
Natomiast 2 października 1702 r. w Wilnie w imieniu podkomorzyca Karpia Mateusz Józef Zubrzycki, generał województwa wileńskiego, w towarzystwie Jana i Pawła Zawadzkich „przyaresztował” u wielebnego Sebastiana, przeora wileńskich karmelitów bosych, dokumenty, poręczenia i prawo zastawne na Nowy Dwór. To właśnie w ich klasztorze, położonym nieopodal Ostrej Bramy, „niemały czas chorował i zmarł" Władysław Ror, stolnik trocki. Pozostałe po nim papiery miały zostać wydane jedynie Karpiowi ${ }^{61}$.

13 października 1702 r. w Wilnie Chryzostom toczył sprawę sądową w Trybunale Głównym z Michałem Mogilnickim. Szczęśliwie udało mu się nie tylko uzyskać uchylenie niekorzystnego wyroku trybunalskiego ferowanego 10 stycznia 1702 r. w Nowogródku, ale także zasądzenie (wskaz) od Mogilnickiego kwoty 2710 zł oraz skazanie go na pół roku wieży (zapewne dolnej) w zamku nowogródz$\mathrm{kim}^{62}$. Z kolei 1 grudnia tegoż roku przed sądem trybunalskim w Wilnie doszło do ponownego procesu $\mathrm{z}$ bernardynkami ze Słonimia. Jednak ze względu na absencję starszej zakonu, wielebnej Petroneli Połubińskiej, reprezentujący Karpia Samuel Koreywa, wojski trocki, niewiele wskórał, a proces przeniesiono do Mińska. Tam Chryzostom wskazywał na spustoszenie majętności luszniewskiej, a w tym zrujnowanie dworu, młyna, budynków folwarcznych, zapuszczenie niegdyś pokaźnego kompleksu stawów rybnych, ale przede wszystkim na „rozpędzenie poddanych”. Wyrokiem sądu siostry zakonne miały zapłacić sumę $10210 \mathrm{zł}$ (szkody w majątku 10 tys. zł, nakłady prawne 210 zł) w ramach zadośćuczynienia ${ }^{63}$. Nie był to jednak koniec batalii sądowej. Następny proces odbył się 27 kwietnia 1703 r. w Trybunale kadencji wileńskiej i 10 października tegoż roku w sądzie ziemskim słonimskim. Już wtedy sprawami prawnymi ze strony zakonnic kierowała nowa przełożona Elżbieta Judycka. Karpiowie, nie oddając 15 kwietnia 1703 r. zastawu w wysokości 5 tys. zł, sami skomplikowali swoją sytuację. Zwrot miał nastąpić w obecności licznego grona urzędników powiatowych: podkomorzego Remiana Połubińskiego, chorążego Aleksandra Bykowskiego, sędziego ziemskiego Michała Połubińskiego, wojskiego Michała Żabki i skarbnika rzeczyckiego Wojciecha Buczyńskiego. Ponadto zakonnice oskarżyły Karpia o wyrządzenie szkód w kwocie 3 tys. zł. Chodziło tu m.in. o dwutygodniowy wypas bydła i koni z Serebryszcz na łąkach luszniewskich, wyceniony na 500 zł. Wobec piętrzących się wzajemnych zarzutów sąd nie kwapił się do jakichkolwiek rozstrzygnięć i sprawę odroczono ${ }^{64}$.

${ }^{61}$ LVIA, SA 4717, t. 2, k. 714-714v.

${ }^{62}$ LVIA, SA 392, k. 1032-1033v. Pozew w Wilnie wręczył Mateusz Józef Zubrzycki. Stosowne zeznanie złożył przed Michałem Koszczycem, pisarzem ziemskim wileńskim. 5 II 1702 r. wydano wypis z ksiąg grodzkich nowogródzkich. Na procesie Karpia reprezentował Michał Antoni Kopeć, oboźny piński.

63 LVIA, SA 393, k. 25-26v.

${ }^{64}$ NGAB, f. 1785, inw. 1, nr 47, k. 21-24v. Pozew przekazał Marcin Bogdanowicz. Patronem bernardynek był Krzysztof Żukowski, regent grodzki słonimski. Poza tym w sprawę zamieszani byli także: p. Bohuszowa, Jan Ancuta, skarbnik brzeski i Michał Kopeć, oboźny piński. 
W międzyczasie Karp borykał się jeszcze z innymi adwersarzami. Byli to niedalecy sąsiedzi Michał i Helena z Ozarewiczów Jacyniczowie, strażnikowie słonimscy oraz ich synowie Jan i Stanisław. Niepoślednią rolę w konflikcie odegrał także Stanisław Kotowski, towarzysz chorągwi pancernej „Jaśnie Oświeconego księcia Wiśniowieckiego, hetmana Polnego WXL”. To właśnie za jego przyczyną żołnierze chorągwi „pozostając kilka niedziel w bliskim sąsiedztwie dóbr Chryzostoma Karpia, podkomorzyca ziemi bielskiej" 24 czerwca 1702 r. najechali karpiowskie Serebryszcze. W nocy urządzili sobie biesiadę kosztem dworu, a nawet „zbytki czynić czeladzi [dworskiej] kazali”. Nazajutrz z majątku wyprowadzili 58 sztuk bydła, a w tym znaczną część jałówek. Zagrabione krowy spędzili do majątku Jacyniczów Isajewicze ${ }^{65} \mathrm{w}$ powiecie słonimskim. Pozbawione matek 24 cielaki wkrótce padły z głodu. W sumie straty Karpiów wyniosły $1500 \mathrm{zł}$. Następnego dnia napastnicy powrócili z żądaniem zapłaty kilku tysięcy złotych haraczu. Początkowo poszkodowany chcąc odzyskać stado, udał się z interwencją do księcia Michała Serwacego Wiśniowieckiego ${ }^{66}$. Skutek audiencji był jednak marny. Pomimo skasowania przez księcia paletu żołnierskiego (obowiązku wypłaty kontrybucji) do zwrotu bydła nie doszło. Nie wiemy, czy był to jedynie wybieg księcia, czy też rozzuchwaleni wojskowi faktycznie zlekceważyli obowiązek oddania zarekwirowanych zwierząt. W każdym razie Karp nie czekając na dalszy rozwój wypadków, zebrał pospiesznie swoich poddanych i ruszył na Isajewicze Jacyniczów. Bez większych przeszkód zawładnął majętnością. We dworze dostał się do izb, skarbca i zabrał stamtąd różne dokumenty oraz precjoza. Wiemy, że przy okazji bardzo przestraszył właściciela. $Z$ folwarku odzyskał 40 sztuk bydła, a protestującego ciwuna dworskiego mocno poturbował. Jacyniczowie wycenili straty na 6 tys. zł. Niestety rewanż z ich strony nastąpił dość szybko. 25 września 1702 r. ta sama jazda, licząca kilkadziesiąt koni doborowego żołnierza, idąc do Słonimia, w odwecie najechała dwór i wieś Iwankowicze. Żołdacy zabrali 31 sztuk bydła i poczynili szereg dodatkowych szkód. Później sąd trybunalski oszacował je na 4535 zł. Tę sumę Jacyniczowie - „agresorzy dóbr szlacheckich ziemskich” - mieli w ramach rekompensaty zapłacić Karpiowi. W werdykcie podkreślono, że jego dobra w żadnym razie „nie podlegały ciężarom żołnierskim”. Procesy z Jacyniczami toczyły się w grodzie słonimskim 30 czerwca i 30 września 1702 r. Poza tym wydano dwa uniwersały książęce, $w$ tym jeden kasujący palet, a drugi ochronny dla Karpiów ${ }^{67}$. Z tego też powodu 22 listopada 1702 r. podkomorzyc

${ }^{65}$ Leżą w gm. Derewnia pod Słonimiem, ok. 7 km na zachód od Iwankowicz.

${ }^{66}$ Hetman polny litewski w latach 1702-1703 i 1707-1709. Ostatni męski potomek rodu, zm. 18 IX $1744 \mathrm{r}$.

${ }^{67}$ LVIA, SA 392, k. 1838-1841v. Sprawę Karpiów prowadził Samuel Koreywa, wojski trocki. Ze strony Jacyniczów nikt się nie stawił, chociaż 5 października w Isajewiczach otrzymali pozew od Marcina Bohdanowicza, woźnego pow. słonimskiego. Z kolei 27 listopada woźny Piotr Żynza ogłosił ich infamisami. 
Karp wniósł skargę do Trybunału. Obie zwaśnione rodziny znały się od dawna, a nawet prowadziły wspólnie interesy. Już w 1690 r. Michał Jacynicz, strażnik słonimski, trzymał w zastawie 1 dym od Karpia ${ }^{68}$. Najpewniej te właśnie kontakty stały się zarzewiem ostrego konfliktu. Poza tym wydaje się, że adwersarze liczyli na osłabienie domu karpiowskiego równoczesnym zaabsorbowaniem w o wiele groźniejszy zbrojny spór z rodziną Szyszków ze Świran ${ }^{69}$. Dodatkowe uwikłanie z pewnością zmniejszało ich zdolności obronne.

${ }^{68}$ ML. Podymne nowogrodzkie 1690, s. 144.

${ }^{69}$ Dzięki dokumentowi „Weryfikacya graniczna gruntów, łąk, lasów świrańskich y Puszczy za Połonką w powiecie słonimskim" z 24 XI 1728 r. dowiadujemy się, że areał ten pierwotnie wchodził w skład dóbr Połonka. Pod koniec XVI w. jej właścicielem był Bartosz Brzuchański. Majątek podzielił między siedmiu synów: Waleriana, Albrychta (właściciel Iwankowicz), Konstantyna, Stanisława, Aleksandra, Marcjana i Krzysztofa. Przed 15 XI 1612 r. grunty świrańskie otrzymał Konstanty Brzuchański. Z tym że ostateczny podział dóbr ojcowskich Brzuchańscy przeprowadzili dopiero 13 I 1618 r., a umowę przyznali 15 tego miesiąca w ziemstwie słonimskim. Dopiero po tym Konstanty Brzuchański wystawił dwór w Świranach. Majątek obejmował wówczas 50 włók puszczy, 7 włók i 24 morgi gruntu dwornego. Powierzchnię obliczono według pomiaru Aleksandra Kaszyca z 15 XI 1612 r. Dziedzic dwukrotnie wstępował w związki małżeńskie. Za pierwszym razem ożenił się z panną Wrynianką (lub Urynianką), umarłą bezpotomnie. Po niej pojął Aleksandrę Hołubównę, z której spłodził cztery córki: Zofię, Krystynę, Helenę i „panią Jasińską". Z dóbr ojcowskich zostały spłacone przez drugiego męża Aleksandry Hołubówny Konstantynowej Brzuchańskiej, Mikołaja(?) Koncewicza, podkomorzego pińskiego. On z kolei 24 X 1652 r. pozostawił Świrany następnej żonie, de domo Słotwińskiej primo voto Kierdejowej, secundo voto Koncewiczowej. Wdowa 30 V 1664 r. zastawiła majątek Romanowi Szyszce, skarbnikowi połockiemu. Już 2 II 1666 r. oddał on „wlewkiem” ziemię panu Ordyńcowi, a ten 8 XII 1667 r. „wlewkiem transfundował” Chaleckiemu. 27 IX 1676 r. spłacił go Roman Szyszka, skarbnik połocki. Przy czym 1 II 1679 r. Koncewiczowa de domo Słotwińska primo voto Kierdejowa oddała Świrany swoim synom Michałowi i Andrzejowi Kierdejom, którzy 14 IX 1700 r. odsprzedali je Janowi Romanowiczowi Szyszce, pisarzowi grodzkiemu słonimskiemu. Właścicielem był krótko. Po jego śmierci 7 V 1702 r. („,a został zabity przez poddanych karpiowskich z niechęci”) i po ustaniu dożywocia Janowej Szyszczyny, późniejszej Zienowiczowej, pani Szyszczyna, wojska połocka i babka Jana Janowicza Szyszki, 25 IV 1716 r. oddała w zastaw Świrany Stefanowi Haraburdzie, pisarzowi ziemskiemu nowogródzkiemu. 25 VI 1726 r. Jan Janowicz Szyszka sprzedając majątek (aktykacja 28 XI 1726 r.), postanowił przywrócić stare granice i odzyskać zagarnięte przez sąsiadów grunty. Zresztą przynaglił go do tego sam Haraburda. Już 9 X 1728 r. osznurowano sporny areał, a termin zakończenia pomiarów podkomorzy wyznaczył na 15 listopada tr. Odpowiedzialni za nie byli Mikołaj Szymak, komornik grodzieński i Mateusz Zdanowicz, mierniczy grodzieński. Przede wszystkim chciano zweryfikować, czy areał majątku faktycznie wynosi 45 włók. W efekcie, widząc rozbieżności obszarowe, do Świran przyłączono „bagno Kłoda oraz bagno od pól niżej młynicy świrańskiej ciągnące się do Kłody z zajęciem po części pól od Zwierowców [...] z mogiłkami staremi wewnątrz znajdującymi się". Wówczas grunt ten był obsiany zasiewem żytnim. Wcześniej tymi enklawami miał zawiadywać zarówno podkomorzy Koncewicz, jak i Remigian Szyszka, wojski i podwojewodzi połocki. Potwierdziło to dziewięciu poddanych świrańskich, dodając, że rewiry te po śmierci Szyszki zostały włączone do Zwierowszczyzny przynależnej Luszniewowi. Następnie 24 XI 1728 r. kolejnych czterech poddanych świrańskich (Mikita Kiryk, Jaśko Sieńko, Jaśko Dzierman, Hryhor Karakulka) zeznało pod przysięgą, że poprzednio Świrany liczyły 50 włók. Ponadto Marcjan Pruski, prowincjał prowincji 
Trzeba podkreślić, że faktycznie waśnie Karpiów z drugimi bezpośrednimi sąsiadami Szyszkami były znacznie poważniejsze, a nawet wręcz niebezpieczne. Adwersarze należeli do zamożnej i wpływowej szlachty powiatu słonimskiego. Co prawda w 1690 r. Roman Szyszka zaprzysiągł w Połocku podatek jedynie z 5 dymów ze Świran ${ }^{70}$, ale mieli oni jeszcze inne dobra, właśnie w województwie połockim. Poza tym Roman Szyszka dwukrotnie był deputatem do Trybunału ${ }^{71}$ - w 1679 r. jako pisarz grodzki połocki i w 1694 r., będąc już wojskim połockim. Także jego synowie pełnili funkcje deputackie: Jan w $1701 \mathrm{r}^{72}$ oraz Daniel Kazimierz w latach 1713,1722 i $1728^{73}$.

Trudno dziś wyrokować, co stało się zarzewiem tego konfliktu i która z rodzin go zainicjowała. Niemniej jednak obie sromotnie w nim ucierpiały. $Z$ pewnością do znacznego zaognienia stosunków doszło zaraz po osiedleniu się na stałe Szyszków w Świranach, czyli po 14 września 1700 r. Niestety spór od początku przybrał dość gwałtowny charakter, co świadczy o dużej zapalczywości obu hardych szlachciców. Charakterystyczne jest to, że wzajemne animozje, z biegiem czasu potęgując nienawiść, doprowadziły do morderstwa ${ }^{74}$. Pierwsze odnotowane, 24 listopada 1700 r., w księgach trybunalskich zdarzenie miało miejsce „na Popisie Święto Michalskim w Słonimie". W owym czasie Jan Szyszka, stolnik brasławski ${ }^{75}$ i pisarz grodzki słonimski, mający widocznie jakąś zadawnioną niechęć do Chryzostoma Karpia, napadł na jego ludzi: „konie, rumaki, urządzenia, strzelbę, szable, suknie, naszedłszy na gospodę, mocno gwałtownym sposobem zabrał, pocztowych przy pocztach zostających zbił, zmordował i skrwawił"76. Skradzione sprzęty wyceniono na 3 tys. zł. Wydaje się, że nie był to jego pierwszy występek. Źródła charakteryzują go jednoznacznie: „I[ch]m[ość] P[an] Jan Szyszka, pisarz grodzki słonimski zostając w bliskim żałującego [Karpia] sąsiedztwie nie będąc nigdy w swej zawziętości pohamowanym, ustawiczne najazdy, gwałty, wiolencje

ruskiej dominikanów, także dał „na piśmie zlecenie” w tej kwestii. W rezultacie dokonano weryfikacji granicy we wszystkich spornych miejscach i przeprowadzono stosowne korekty; zob. NGAB, f. 1839, inw. 1, nr 2, k. 62-82. Trzeba ponadto zaznaczyć, że A. Boniecki (idem, Herbarz polski, t. 2, Warszawa 1900, s. 117) informuje o jedynej żonie Bartosza Brzuchańskiego, Annie Szunkównie (1598, pow. słonimski).

${ }^{70}$ ML. Podymne nowogrodzkie 1690, s. 129.

${ }^{71}$ Deputaci Trybunału Głównego Wielkiego Księstwa Litewskiego 1582-1696. Spis, red. A. Rachuba, oprac. A. Rachuba, H. Lulewicz, Warszawa 2007, s. 340, 392.

72 Deputaci Trybunału Głównego Wielkiego Księstwa Litewskiego 1697-1794. Spis, red. A. Rachuba, oprac. A. Rachuba, P.P. Romaniuk, współpr. A. Macuk, J. Aniszczenko, Warszawa 2004, s. 43.

73 Ibidem, s. 86, 118, 140.

74 S. Karp, Crimen w życiu szlachty polskiej. Obraz zatargu sąsiedzkiego w Rzeczypospolitej XVIII w., „Podlaski Kwartalnik Kulturalny” 2011, nr 3, s. 7-19.

75 Jan na Berezowie Szyszka został odnotowany jako stolnik brasławski 26 II 1691 r.; zob. Urzędnicy Wielkiego Księstwa Litewskiego. Spisy, t. 1: Województwo wileńskie, XIV-XVIII wiek, red. A. Rachuba, oprac. H. Lulewicz, A. Rachuba, P.P. Romaniuk, Warszawa 2004, s. 595.

${ }^{76}$ LVIA, SA 392, k. 1877; SA 4717, t. 2, k. 612. 
na majętność Serebryszcze y na majętność Iwankowicze w powiecie słonimskim leżące najeżdżając czynił, poddanych żałujących [Karpiów] po drogach y po różnych miejscach bił, mordował"77. Również i teraz Szyszka nie poprzestał na tym ekscesie. 20 września 1701 r. łamiąc dekret sądu trybunalskiego kadencji mińskiej, napadł na majętność Serebryszcze. Opis tego zdarzenia podaje: „[Szyszka] z niemałą gromadą ludzi pode dwór Serebryszcze nazwany w powiecie słonimskim leżący, armata manu $^{78}$ podjechawszy zasadzki uczyniwszy chcąc żałującego [Karpia] o śmierć przyprawić na pojedynek wyzwał". Chryzostom Karp rzuconego wyzwania nie przyjął i przezornie nie wysunął się spoza dworskiego ostrokołu. Zapewne faktycznie bał się zdradzieckiego postrzału, bo „w szabli” - jak wiemy był dobrze zaprawiony. Należy też dodać, że siedziba podkomorzyca miała charakter obronny i posadowiona była na sporym wzniesieniu, stąd ewentualny szturm najezdników bez elementu zaskoczenia spowodowałby u nich znaczne straty. Po nieudanej próbie wywabienia Karpia na zewnątrz Szyszka zaniechał frontalnego ataku i zaczął panoszyć się na terenie całej majętności. Niedaleko od centrum „na grobli nazwanej Czarnej, między Luszniewem y Iwankowiczami na dobrowolnej drodze" ograbił powracającego z jarmarku karpiowskiego bojarzyna Prokopa Narbuta, wyładował złość właśnie na tym nieszczęśniku. Nie tylko okradziono go z pieniędzy, konia i nabytych na targu w Łotwiczach rzeczy, ale pokrzywdzonego „kijami okrutnie zbiwszy, zmordowawszy zęby powybijawszy, kości pogruchotawszy za nieżywego na drodze porzuciwszy, [Szyszka] odjechał"79. Agresor nie poprzestał na tym i chełpiąc się zwycięstwem, zniszczył znaczną część granicznych kopców. W rezultacie zagarnął spory fragment karpiowskiego majątku. Dalej, korzystając z bezsilności właściciela, z pozostałych gruntów „żyto pożoł" i drewno z lasu wywiózł.

Na odwet nie trzeba było długo czekać. Już 3 października 1701 r., wykorzystując wyjazd Szyszki do Nowogródka na posiedzenie Trybunału Głównego Wielkiego Księstwa Litewskiego, Karp ze swymi sługami napadł na niego w pobliżu Luszniewa „przeciwko grobli tamecznej rzuciwszy się strzelając mało o śmierć ujeżdżającego [Szyszkę] nie przyprawili”. Poraniono jego służących Antoniego Łukomskiego i Bazylego Wasilewskiego. Należy przyznać, że ludzie Karpia z dużą zawziętością ścigali uciekiniera, do tego stopnia, że „chartów dwóch z muszkietu za Delatorem [Szyszką] biegnących postrzelali"80. Wypada też odnotować, że pomimo poniesionych strat Karp przegrał procesy 10 i 24 listopada $1701 \mathrm{r}$. w Nowogródku. Skazano go na infamię. Wydaje się, że było to nieuniknione, skoro sam Szyszka był wtedy deputatem trybunalskim, a powyższą rozprawę prowadzili jego znajomi i koledzy sędziowie.

77 LVIA, SA 392, k. 1877; SA 4717, t. 2, k. 612.

78 Armata manu (łac. ) - zbrojnie.

79 LVIA, SA 392, k. 1877.

${ }^{80}$ Ibidem, k. 1876-1876v. 
Rozzuchwalony bezkarnością Szyszka coraz częściej zapuszczał się na teren włości Karpia, wyrządzając raz po raz rozliczne szkody w jego gospodarstwie. Prym wiódł zwłaszcza w udręczaniu tamtejszych poddanych. Zapewne podkomorzyc był już wtedy u kresu wytrzymałości, gdyż zdecydował się na wyjątkowo drastyczne posunięcie. Zresztą właśnie od tego momentu dalszy bieg wydarzeń potoczył się błyskawicznie. W nocy z 30 kwietnia na 1 maja 1702 r. Karp zebrał najbardziej zaufanych ludzi i zasadził się z nimi pod dworem w Świranach ${ }^{81}$. Plan był prosty: po podpaleniu budynków folwarcznych „człek” Karpia, niejaki Hryszko Myśliwiec miał zgładzić właściciela. Tak też zrobiono. Hryszko Myśliwiec „w nocy z muszkietu przez okno do [Jana Szyszki] w izbie będącego złożył się y strzelić chciał [...] y pewnie, by w samym dworze świrańskim mieszkaniu nieboszczykowskiego o śmierć przyprawił, gdyby dziedzic nie porwał się z izby na krzyk ludzki”" . W efekcie zgorzał jedynie folwark łącznie ze „świrenkami chłopskimi”. Straty materialne sięgnęły 10 tys. zł. Szyszka cudem uszedł z życiem i w rewanżu 4 maja 1702 r. ponownie próbował schwytać Prokopa Narbuta. Uzyskawszy wiadomość, że poddany Karpia wybiera się na targ do Horodyszcza w województwie nowogródzkim, Szyszka „biegł za Onym w tropy, chcąc Onego o śmierć przyprawić y tam w mieście Horodyszczu po różnych miejscach na zabicie Onego szukał”. Tymczasem Narbut szczęśliwie wymknął się z opresji i niespokojny czas przeczekał u zaufanych znajomych. Natomiast Szyszka wracając po niefortunnym pościgu, „kijami okrutnie kazał zbić” innego napotkanego poddanego Karpia, Jewtucha Kmitę. Nieszczęśnik ten wracał do domu z zakupionym na targu wołem. Ludzie Szyszki dali upust swojemu okrucieństwu, a na koniec pozostawili go na wpół żywego na drodze. Zmaltretowanego przypadkowo napotkawszy „chłopi cudzej włości, na wóz włożywszy zawieźli do wsi jednej pod Horodyszczem" "83, ratując mu w ten sposób życie.

Po tym zajściu podkomorzyc Karp postanowił definitywnie rozprawić się z uciążliwym i co gorsza niebezpiecznym sąsiadem. Zdawał sobie sprawę, że musi to zrobić skutecznie. Stąd 6 maja „napoiwszy i uzbroiwszy” w pięć muszkietów wiernych strzelców z Serebryszcz, nazajutrz w niedzielę (7 maja) ruszył pod stary dwór świrański. Trzon grupy stanowili wypróbowani ludzie: Prokop Narbut z muszkietem i oszczepem, Kozak strzelec z dwoma muszkietami i Hryszko Myśliwiec także z dwoma muszkietami. Do pomocy Karp „przydał jeszcze chłopów z różnych wsi swoich z kosami, oszczepami y kijami”. Tylko niektórych zaopatrzył w rusznice. W sumie w wyprawie uczestniczyło prawie 80 osób. Jej celem było zgładzenie Szyszki za wszelką cenę i jak wynika z akt sądowych: „pod gardłem przykazane było potajemnie". Tymczasem w trakcie przemarszu miejscowi

\footnotetext{
81 Ibidem, k. 1873.

82 Ibidem, k. 1873v.

${ }^{83}$ LVIA, SA 4717, t. 2, k. 612-615v; SA 392, k. 1872-1879v.
} 
informatorzy donieśli Karpiowi, że Szyszka wraca od Krzysztofa Komorowskiego, kuchmistrza litewskiego, starosty wołkowyskiego, z majątku Żeleźnica w województwie nowogródzkim. Chryzostom błyskawicznie zrewidował zamierzenia i ze swoją watahą zaczaił się „o jedną milę od dworu świrańskiego w puszczy przy samej granicy” majątku Szyszków „,z gruntem Myskim”" Wykorzystując zapas czasowy, „osieki poczyniwszy, drogę zarzucili drzewem tak, aby nie było którędy nie tylko wozem [ale] y konno, ani pieszo wyjechać ani wyniść". Gdy niczego nieświadomy Szyszka wjechał w zasadzkę, pierwszy „tedy zaraz Kozak strzelec z muszkietu sobie danego do nieboszczyka [Szyszki] strzelił, a Myśliwiec drugiego muszkietu dwoma kulami nabitego zabiegłszy w oczy nieboszczykowi strzelił y obiema kulami w lewy bark [Szyszkę] ugodził y gdy czeladź nieboszczykowska postrzegłszy wielką zasadzkę ludzi y pana podstrzelonego pouciekała a nieboszczyk z tego impetu rzucił się z wozu każąc sobie konia dać tamże nazywający się chłop Narbut, oszczepem jako zwierza jakowego z zasadzki przypad[1]wszy w pleca uderzył, tak iż oszczep przez pleca na wylot przeniknąwszy serce y piersi przeszedł y wnętrzności za sobą wywlókł, a po tym y drugi chłop przypad[łw]szy także oszczepem w głowę z prawego boku w samą skroń uderzył tak, że oszczep przeszed[ł]szy mózg y kości, końcem w lewy róg na wylot przeszedł, od którego uderzenia mózg na tymże miejscu wyprysł y skorupę wszystkiej głowy zgruchotał"85. Jan Szyszka musiał być faktycznie wyjątkowo znienawidzony przez napastników, ponieważ „bez wszelkiej litości, okrucieństwa zażywając, to jest rozebrawszy [ciało] z odzienia, postawiwszy na ziemi y kijami popodpierawszy do niego strzelali, w którym ran kulowych po wszystkim ciele y oszczepami wiele ran pozadawali tak, że zliczyć trudno było. A na ostatek [nagie] ciało zawlek[1]szy w las, w błoto bagniste y tam one błotem y chrostem zarzucali, aby nikt znaleźć nie móg”" ${ }^{\circ}$. Należy tutaj dodać, że napastnicy zrabowali „wszystko co na nieboszczyku y przy nieboszczyku było". Zdobycze wrzucono na wóz i razem z pokiereszowanym woźnicą zabitego Kasprem Mazurem przewieziono do siedziby Karpia w Serebryszczach. Ze skargi wdowy dowiadujemy się, że łupem padły następujące ruchomości: „kontusz krwawego koloru letni z guzami y pętlicami ${ }^{87}$ łańcuszkowemi szczerozłotemi wiszącemi kosztujący złotych dwieście, żupan atłasowy żółto gorący bawełną prześciełany kosztujący złotych sto dwadzieścia, amelikę ${ }^{88} \mathrm{z}$ łańcuchem srebrno złocistym we troje złożonym kosztującą złotych dwieście, czapkę sobolą niszkową kosztującą złotych pięćdziesiąt, pas muślinowy kosztujący złotych dwadzieścia, a szablę złocistą z sznurem jedwabnym kosztującą talarów bitych sto, sztuciec z łyżką y nożem szczyrozłote kosztujące złotych

${ }^{84}$ Nowa i Stara Mysz pod Baranowiczami.

${ }^{85}$ LVIA, SA 392, k. 1874.

${ }^{86}$ Ibidem, k. 1874v.

${ }^{87}$ Ozdobne zapięcie dawnego ubioru lub rodzaj naszycia w postaci pętelki, szamerowanie.

${ }^{88}$ Puszka, puzderko, torba, a także rodzaj ładownicy. 
pięćset, spinkę u koszuli szczerozłotą z rubinami kosztującą złotych dwadzieścia y sześć, pierścień szczerozłoty kosztujący złotych trzynaście, z szkaplerzem czerwonych złotych sto, muszkiet kosztujący talarów bitych piętnaście, wóz kryty francuski kosztujący złotych czterysta, koni dobrych para z szorem kosztujące złotych sześćset, kaftan y inne rzeczy kosztujące złotych sto"89.

Po trzech dniach podkomorzyc Karp rozkazał służbie wydobyć ciało Szyszki $z$ bagna $i$ „w cerkwi luszniewskiej w ziemi zakopać”. Tak też zrobiono, przy czym wdowy do pochówku nie dopuszczono. Nie był to jednak kres wendety, Szyszkowa wezwała bowiem na pomoc braci zabitego, Daniela i Bazylego. Starszy, Daniel Kazimierz Szyszka, cześnik połocki, „wziąwszy wiadomość” o tym „dla odległości miejsca y kraju tego w niedziel dwie ledwo” przybył „w powiat słonimski do Świran”. Nastąpiło to 17 maja. Na niego z kolei przygotował zasadzkę szwagier Karpia, Gerwazy Wołk-Łaniewski, wojski mozyrski i starosta przeroski. Wraz z gromadą kilkudziesięciu ludzi zaczaił się w lesie niedaleko Mołczadzi. Tymczasem w porę ostrzeżony cześnik Szyszka pojechał inną drogą i cało dotarł do Świran.

Warto podkreślić, że rodzina Szyszków początkowo podjęła działania prawne. W pierwszej kolejności „windykowali” z Luszniewa ciało zabitego, a następnie 19 maja „prezentowali je w mieście JKM Słonimie”. Był to przecież namacalny dowód zbrodni. Równocześnie złożyli też skargę do sądu grodzkiego słonimskiego o „exces y kryminał popełniony” przez Karpia ${ }^{90}$. Na tym jednak nie poprzestali i oprócz wykorzystania możliwości jurystycznych sami postanowili wymierzyć sprawiedliwość. Tego samego dnia po przybyciu, tj. 17 maja 1702 r., Daniel Kazimierz Szyszka „w niebytności” Chryzostoma Karpia „mocno, gwałtownym sposobem”, w kilkadziesiąt koni, „Z różnym do boju należącym orężem y strzelbą”, najechał majątek Serebryszcze. Zaskoczeni błyskawicznym napadem mieszkańcy nie zdołali powstrzymać naporu licznego przeciwnika. Widząc panujący dookoła bezład, osamotniona Karpiowa pospiesznie rzuciła się do ucieczki. Tragizm tej sytuacji potwierdzono na procesie sądowym: „[Ewa Teresa Karpiowa] ciężarną będąc a unosząc swoje zdrowie przez okno ledwo do lasu ujść mogła y tamże płód martwy z przestrachu [i] niewczasu poronić musiała, a po tym, aż do Mołczadzi we mdłości będąc, do siostry swojej Jejm[o]ści Paniej Łaniewskiej, wojskiej mozyrskiej piechotą całą milę lasem resztę zdrowia swego ledwo unieść mogła, dziecię [pozostałe na miejscu we dworze - S.K.] żałujących [Karpiów] w pół roku będące y dalej zostające dziewczynkę [napastnicy] przestraszyli”"1. Na skutek tych wydarzeń dziecko zmarło 29 czerwca 1702 r. Będącego na majdanie dworskim szlachcica Mroczkowskiego „zawiadowcę serebryskiego” napastnicy „zbili, zmordowawszy do Kompasu uwiązawszy śrzód podwórza rozstrzelać chcieli",

\footnotetext{
89 LVIA, SA 392, k. 1874.

90 Ibidem, k. $1875 \mathrm{v}$.

91 Ibidem, k. 1878.
} 
ale koniec końców „szczęśliwie” ukradli mu jedynie „konia y inne rzeczy” oraz "jakoweś skrypty” wymusili. Pobili kańczugami także gospodynię dworską. Na domiar złego rozzuchwaleni agresorzy zgwałcili pięć tamtejszych kobiet (Olesię Kmiciankę, Tacianę Piekarykową, Nastazję Paśnikówną, Awdocię Apaniukówną, Tacianę Mieleszkówną) „niemało exorbitancyj [z nimi] poczyniwszy”. Ponadto dwóch chłopów (Wasila Dudczyka, Sawkę Lewczyka vel Lewszyka) do „prywatnego więzienia” w Świranach „zabrali”"2 . Po opanowaniu dworu napastnicy rozpoczęli regularną grabież. Do cna okradli także dworskie świrny ${ }^{93}$. Ich łupem padło: bydło, konie, klejnoty, gotówka, złoto, srebro, cyna, miedź, szaty, „ochędóstwa różne”, futra, urządzenia, muszkiety, flinty, pistolety, szable oprawne, kobierce, a nawet buty, czyli „wszelkie supellectilia [sic!]”. Oprócz tego złupili 18 świrnów chłopskich, pobierając z nich „mięsiwa różne, słoniny” itd. Na koniec pozostałe wiktuały, których nie mogli zabrać, poniszczyli. Wszystkie zrabowane dobra na rozkaz Szyszki przetransportowano do dworu bratowej w Świranach, „obracając na swój pożytek". Straty Karpiów oszacowano na 50 tys. zł.

Po tych bezeceństwach, rozochoceni bezsilnością Karpia, 28 tegoż miesiąca najechali jego drugi majątek. Ich głównym celem było pojmanie chłopów z Iwankowicz, tak aby pozbawić Chryzostoma siły roboczej i doprowadzić majątek do ruiny. Szczęśliwie mieszkańcy wyjechali w tym czasie na targ do Mołczadzi. W ręce napastników wpadł jedynie chłop Samuel Jabłoński. Pobito go i torturowano $^{94}$. Najazd na Iwankowicze Szyszkowie powtórzyli trzy dni później, 31 maja. Wówczas to porwali „syna Audzieyczykowego”, którego „gdzieś zadzieli”" tycznie jego dalsze losy nie są znane. Karpiowie oprotestowali napady przed Trybunałem 14 i 24 lipca oraz 28 sierpnia 1702 r. ${ }^{96}$ Owe protesty nie przyniosły spodziewanych rozstrzygnięć, choć część wcześniejszych werdyktów skasowano. Natomiast proces trybunalski z powództwa strony przeciwnej odbył się 11, 13, 25 i 27 października, a następnie 10, 17 i 24 listopada 1702 r. Szyszków reprezentował Michał Kopeć i Stefan Frąckiewicz. Oprócz Karpiów i Wołk-Łaniewskich oskarżono także strzelców Prokopa Narbuta, Hryszka Myśliwczyka, Kazimierza Kozaczka, trzech strzelców Łantasiów, Krahańskiego, Swiertka, Józefa Cieślę, Wasila Dudkę (!) i Lewczyka. Ciążył na nich bardzo poważny zarzut napadu zbrojnego na dwór świrański. Proces i tym razem nie przyniósł rozstrzygnięcia, Karp bowiem wytrwale utrzymywał, „czego w samej rzeczy nigdy nie było y tego dowieść nie można”. W rezultacie sąd ograniczyl się do wyznaczenia nowego składu sędziowskiego. Miał on rozpatrzeć sprawę 22 grudnia 1702 r. ${ }^{97} \mathrm{Na}$ ostatnim

\footnotetext{
92 Ibidem.

93 Spichlerze.

${ }_{94}$ LVIA, SA 4717, t. 2, k. 612-615v; SA 392, k. 1878v.

95 LVIA, SA 392, k. 1879; czytaj: zapodzieli.

${ }^{96}$ Ibidem, k. 1872v.

${ }_{97}$ LVIA, SA 4717, t. 2, k. 612-615v; SA 392, k. 1879v.
} 
terminie w Wilnie sprawę rozpatrywali sędziowie Bogusław Leon Błuś, krajczy oszmiański, Jan Michał Buchowiecki, podczaszy grodzieński, Jan Ciechanowicz, łowczy smoleński, Jan Jasiewicz, podstoli witebski. Ponieważ wszyscy czterej byli - jak twierdzili pozwani - zaprzyjaźnieni z domem Szyszków, Karpiowie przegrali sprawę z kretesem. Sytuacja powtórzyła się 26 lutego 1703 r. i pomimo poniesionych strat Karpiowie mieli zgodnie $\mathrm{z}$ werdyktem sądu zapłacić sumę 10 tys. zł. Stąd też 4 maja 1703 r. wspólnie z Gerwazym i Anną (!) z Niewiarowskich Wołk-Łaniewskimi, wojskimi mozyrskimi, wnieśli do ksiąg surogatorskich wileńskich protest przeciwko Annie z Kostrowickich Romanowej Szyszczynie, wojskiej połockiej, synom Danielowi Kazimierzowi, cześnikowi połockiemu, staroście berżnieńskiemu i Bazylemu Szyszkom oraz wdowie Elżbiecie Pilance Janowej Szyszczynie, stolnikowej brasławskiej i pisarzowej grodzkiej słonimskiej. W skardze podważali obiektywizm wileńskiego werdyktu z 1702 r. Wskazywali, że ferowało go „czterech Ichm[ościów] Colegów swoich [Szyszków] a sędziów Głównego Trybunału, [którzy] wspólnej radzie i namowie będących [sprawę] przeciągnęli" ${ }^{\prime 9}$. Skutkiem tego następna rozprawa została wyznaczona dopiero w 1703 r. na kadencji mińskiej. Tam jednak z bliżej nieokreślonych powodów nie dopuszczono jej na wokandę. Co ciekawe, po tych kompletnie jałowych i nic niewnoszących procesach Karpiowie wycenili poniesione nakłady prawne na kwotę 10 tys. zł. Przede wszystkim upomnieli się o swoich czterech wiernych poddanych: Prokopa Narbuta, Kazimierza Kozaka i dwóch Łantaszyków (Łantasiów). Wskazywali, że aresztowani na mocy wyroku z 26 lutego 1703 r. - wydanym zreszta podczas nieobecności właścicieli - są niewinni i że działali „czysto w obronie zdrowia swego, ale onych połapawszy do Mińska na Trybunał zaprowadzili tam onych dwóch na śmierć dekretowali a dwóch uwolniwszy nie wiedzieć gdzie ich zadzieli" "99. Chryzostom Karp uparcie twierdził, że 7 maja 1702 r., gdy jego strzelcy znający przejścia łosi i saren szli do lasu na polowanie Jan Szyszko ze swoimi ludźmi zaczął ich osaczać. Miało to miejsce „na dobrowolnej drodze przy granicy czeszewlańskiej, gdzie y puszcza żałującego [Karpia] zostaje, a na samym przechodzie, którędy łosie y sarny z puszczy do puszczy przechodzą zasadzkę uczyniwszy wprzód spytawszy czyje by to strzelcy byli, a gdy powiedzieli, że I[ch]m[ość] P[ana] Karpia, tedy tych strzelców, [Szyszka] powiadając po co tu weszliście, rozpędzać ich po lesie y zabijać począł, w tym razie czy to w obronie zdrowia swego pomienieni strzelcy broniąc się y uchodząc od I[ch]m[oś]ci, który $\mathrm{z}$ nich $\mathrm{w}$ takowym gwałcie strzelił, czyli też $\mathrm{w}$ zamieszaniu takowym od swoich pomocników y czeladzi strzelających I[ch]m[oś]ć Pan Szyszka, pisarz grodzki słonimski zabity został100 [...] Pan Bóg wie jako y od kogo"101. W trakcie procesu

\footnotetext{
98 LVIA, SA 4718, t. 1, k. 418.

99 Ibidem, k. 418v.

100 LVIA, SA 392, k. 1877v.

101 LVIA, SA 4717, t. 2, k. 613.
} 
Karpiowie uskarżali się również, że Szyszka nieraz najeżdżał na Serebryszcze i Iwankowicze, a „poddanych, gdzie mógł dosięgnąć bił, tłukł y przepędzał”. Taka linia obrony zaowocowała uwolnieniem przez Trybunał kadencji mińskiej dwóch pojmanych, lecz pozostali dwaj faktycznie mieli zapłacić gardłem. Z kolei dekret trybunalski wileński potwierdził niewinność podkomorzyca Chryzostoma Karpia, całkowicie uwalniając go od zarzutu zabójstwa. Nieco wcześniej oczyszczono także Wołk-Łaniewskiego z oskarżeń o nastawanie na zdrowie i życie Daniela Kazimierza Szyszki. Sąd uzasadnił: „sam nie zasadzał się y nikogo w mieście y przed miasteczkiem na zasadzkę y na zabicie I[ch]m[ości] Szyszki nie subordynowali”'102. Po uzyskaniu uniewinnienia Karpiom pozostała do załatwienia sprawa kasacji wyroku nakazującego zapłacenie na rzecz adwersarzy kwoty 10 tys. $z^{103}$. Niestety nie wiemy, jak zakończyły się ich starania. Trudno też wyrokować, która ze stron dominowała w konflikcie. Na pewno obronną ręką ze sporu, przynajmniej pod względem prawnym, wyszli Karpiowie i Wołk-Łaniewscy. Sąd ziemski podkomorski, który obradował wiele lat później, od 4 października do 15 listopada 1728 r., wykazał, że po zgonie pisarza grodzkiego Jana Szyszki wszyscy sąsiedzi Świran naruszyli granice, przywłaszczając sobie jakieś fragmenty tego majątku ${ }^{104}$.

102 LVIA, SA 4718, t. 1, k. 418v.

103 Ibidem, k. 418-419v.

${ }^{104}$ Oprócz Karpiów i Wołk-Łaniewskich w sporze granicznym udział wzięli: Wiktor Lindeman, miecznik kowieński, Dominik Bułhak, podstoli smoleński, Jakub Dobrzyński, przeor dominikanów konwentu połońskiego, Antoni Pacyna, Andrzej Przecławski, starosta bialski („z racji opiekuństwa" nad potomstwem zmarłego Antoniego Przecławskiego), Marcjan Szukiewicz, Jan Szatrawa, proboszcz kanoników regularnych laterańskich konwentu słonimskiego („ogromnie las spustoszyli", budując budynki i biorąc drewno na opał), Mateusz Mamulewski z synem, tenutorzy części Łotwicz (Sierki). Ówczesny proces przeprowadzono na podstawie rozgraniczenia Derewnej z Luszniewem i Świranami z 28 IX 1635 r. „Ograniczenie dereweńskie” wykonano na zlecenie Kazimierza Leona na Czerei, pisarza WKL, i Mikołaja pana na Kodniu, chorążego WKL, Sapiehów. Powyższa ugoda została aktykowana w ziemstwie słonimskim 5 X 1728 r. Natomiast lustracja podkomorska wykazała wiele naruszeń granicznych. Na przykład niejaki Marcjan Szukiewicz, zastawnik od Przecławskich, zajął połowę młyna i dwa place w Połonce, które przedtem należały do Świran. Przy okazji zagarnął Żyda Jakowicza (Jakowa, Jakuba) i ogrodnika Bołtuza, mieszkańców tych posesji. Poprzednio była to wspólna własność Konstantego i Albrychta Brzuchańskich. Również 5 X 1728 r. komisja podkomorska rozpoczęła objazd granic „od kopca narożnego granicy dereweńskiej za błotem Trybunowem do Świran należącym, w końcu ściany Łotwicz" (Sierki). Następnego dnia dalej ostatnim duktem. Natomiast 7 X 1728 r. objechano granicę z dobrami Karpiów i Wołk-Łaniewskich. Dnia 8 tego miesiąca do lustrujących dołączył Donat Jan Rewieński, podstarości nowogródzki i plenipotent Haraburdy. Pozwanych reprezentował Kazimierz Stroński, z tym że Karpiowie asekurowali się także drugim patronem, panem Rahozą. Co ciekawe, rodziny Karpiów i Wołk-Łaniewskich już wtedy odseparowały się od siebie. Charakterystyczne, że Karpiowie byli traktowani przez komisję podkomorską jako właściciele Luszniewa, a Wołk-Łaniewscy tylko jako zastawnicy. Pozwy wręczył im 31 VII 1728 r. Józef Paszkiewicz, generał nowogródzki; zob. NGAB, f. 1839, inw. 1, nr 2, k. 62-78v, 79-82. Należy dodać, że 11 X 1728 r. dzierżawcami Świran byli bracia Stanisław, podczaszy ziemi chełmskiej, i Franciszek, Kaznowscy. 
Na domiar złego 5 października 1703 r. Aleksander i Katarzyna z Massalskich Szulcowie upomnieli się u Karpia o zaległe od 1700 r. 713 zł i 22 gr ${ }^{105}$. Sprawa jednak nie jest do końca jasna, ponieważ 18 października 1704 r. Chryzostom procesował się o tę kwotę ze szwagrem Wołk-Łaniewskim. Ponadto jeszcze 11 listopada 1703 r. w Serebryszczach wstępnie umówił się z Aleksandrem Józefem i Katarzyną z Wołłowiczów Uniechowskimi, sędziami ziemskimi mińskimi, że 23 kwietnia $1704 \mathrm{r}$. odda im w trzyletni zastaw ten majątek. Wysokość sumy zastawu ustalono na 21 tys. zł. Umowa przewidywała także możliwość korzystania przez nich $\mathrm{z}$ dwukołowego młyna $\mathrm{w}$ niedalekich Łotwiczach. Tutaj jednak pojawił się szkopuł, ponieważ młyn łotwicki wtedy nie funkcjonował z powodu przerwanej grobli. Stąd też do czasu naprawienia uszkodzeń dziedzic zezwolił zastawnikom na korzystanie z młyna w Iwankowiczach. Poza tym zobowiązał się opłacać dziesięcinę z Serebryszcz na kościół mołczadzki. Płatnością tą obciążył Iwankowicze. Na koniec uzgodniono, że pieniądze z zastawu Karp otrzyma 12 marca $1704 \mathrm{r}$. Trzeba podkreślić, że w tym czasie Serebryszcze były atrakcyjnym kąskiem. Gospodarczo stały na dobrym poziomie, miały 18 dymów. 10 grudnia 1703 r. podkomorzyc potwierdził transakcję przed Trybunałem Głównym ${ }^{106}$. Wydaje się, że głównym powodem czasowego wyzbycia się tej majętności była niechęć właścicieli do życia w miejscu, gdzie doszło do tak wielkiej tragedii rodzinnej. Zerwanie ze starą siedzibą i osiedlenie się na dobre w Iwankowiczach otwierało nowy rozdział w życiu małżeństwa Karpiów, mającego przecież jeszcze do wychowania trójkę małoletnich dzieci (Jana, Franciszka, Annę).

Trochę wcześniej, tj. 5 tego miesiąca także przed sądem trybunalskim Ewa Teresa $\mathrm{z}$ Niewiarowskich primo voto Ferdynandowa Rorowa, stolnikowa trocka, secundo voto Chryzostomowa Karpiowa, podkomorzycowa ziemi bielskiej, przyznała swój list wlewkowy datowany 2 grudnia 1703 r. w Wilnie Kazimierzowi Michałowi i Justynie Olechnowiczównie Dorohostajskiej Żabom, horodniczym połockim. Scedowała $\mathrm{w}$ nim wszystkie pożytki, jakie mogły wyniknąć z toczonego sporu sądowego z ojczymem Felicjanem Kuczborskim, dzierżawcą kadaryskim $^{107}$ i maćkowskim. Rorowie od dawna mieli pilne zobowiązania finansowe wobec Żabów, a nie mogąc się z nich wywiązać - zwłaszcza po śmierci męża - stolnikowa przekazała im posiadany oblig wraz z dokumentami. Było to clou sprawy w procesie przeciwko Kuczborskiemu oraz jego poplecznikom Bogusławowi Dziewiałtowskiemu, podczaszemu trockiemu, Adamowi Niewiarowskiemu,

${ }^{105}$ NGAB, f. 1785, inw. 1, nr 47, k. 27, 31-32v. Wizję lokalną przeprowadził generał Marcin Bogdanowicz w asyście Jana i Pawła Zarzeckich.

106 LVIA, SA 50, k. 1714-1718v. Akt pieczętowali: Franciszek Łukaszewicz, koniuszy słonimski, Gerwazy Wołk-Łaniewski, wojski mozyrski oraz Stanisław Okulicz, miecznik słonimski. Pierwsi dwaj byli bardzo blisko spokrewnieni z Karpiami. Nieco później zastawnikiem 16 dymów w Serebryszczach był Pancerzyński; zob. ML. Podymne nowogrodzkie 1690, s. 141.

107 Kadaryszki obecnie leżą w pow. suwalskim, gm. Rutka-Tartak. 
Stanisławowi Nieciszewskiemu i nieznanemu nam z imienia Jezierkowskiemu/ Jeziorkowskiemu. Wszyscy oni byli zamieszani w fałszerstwo testamentu jej matki, Zofii Heleny z Radzimińskich Frąckiewiczów primo voto Krzysztofowej Niewiarowskiej, secundo voto Janowej Lipnickiej, stolnikowej mozyrskiej, tertio voto Felicjanowej Kuczborskiej. W grę wchodziły całkiem niezłe apanaże, a mianowicie: kamienica $\mathrm{w}$ Wilnie, gotowizny 5 tys. zł i dużo różnorakich ruchomości, łącznie z matczyną biżuterią. Procesy w tej sprawie Rorowa prowadziła 7 maja $1691 \mathrm{r}$. w grodzie trockim, 26 listopada 1692 r. (wspólnie z mężem) i 29 kwietnia 1693 r. (już sama) w sądzie trybunalskim, a następnie 1 września 1693 r. w sądzie asesorskim litewskim i 11 lipca 1696 r. ponownie w Trybunale Głównym. Na tych ostatnich rozprawach Karpiowa skarżyła już tylko jedyną spadkobierczynię po ojczymie, tj. Krystynę z Kurczów Kuczborską. Ona to w efekcie zagarnęła całą tę spuściznę $e^{108}$. Z kolei 6 czerwca 1705 r. Uniechowscy wnieśli do Trybunału Głównego skargę na Chryzostoma o wierzytelność w kwocie 650 talarów. Karp zobowiązał się uregulować dług do 1 listopada 1703 r. w Serebryszczach, ale tego nie uczynił. Podkomorzyc nie pojawił się również na rozprawie, dlatego z miejsca orzeczono jego winę, obwołano infamisem i nakazano zapłacenie poszkodowanym niebagatelnej sumy 2600 talarów oraz $150 \mathrm{zł}$ kosztów prawnych. Powyższe kwoty zabezpieczono na karpiowskich Pierzchowiczach $^{109}$. Jak widzieliśmy wcześniej, Serebryszcze od 23 kwietnia 1704 r. były w posiadaniu skarżących.

$\mathrm{Z}$ dawnego pięknego klucza sapieżyńskiego, w skład którego wchodziło niegdyś 7 zasobnych majętności (Luszniew z wsiami Luszniew, Zwierowszczyzna i Zamościany; Serebryszcze; Iwankowicze ze Skorodyńcami i folwarkiem Łotwicze alias Sierki; Pierzchowicze; Wysock z wsiami Błoszna ${ }^{110}$ i Wiszowa; Dukrów oraz Plechów) przy Chryzostomie Karpiu pozostały już tylko Iwankowicze i Pierzchowicze. Ta ostatnia majętność wróciła do rodziny po długim okresie zastawiania u różnych kontrahentów. Naturalnie oba dwory miały też kilka mniejszych przysiółków.

Następna wzmianka o podkomorzycu Karpiu pochodzi ze spisu dymów powiatu słonimskiego sporządzonego niedługo po $1711 \mathrm{r}$. Podano tam, że Karp z Iwankowicz wniósł podatek z 4¹/4 i 6 dymów ${ }^{111}$. Natomiast specyfikacja

108 LVIA, SA 50, k. 1628-1631v. Zapis wlewkowy podpisali: Stefan Korczyc, miecznik słonimski, Gerwazy Wołk-Łaniewski, wojski mozyrski oraz Jan Dominik Pacewicz-Pomarnacki, koniuszy wiłkomierski.

109 LVIA, SA 399, k. 1401-1402v. Uniechowskiego reprezentował Aleksander Hordziejewski, miecznik wileński. Karp się nie stawił, chociaż odebrał w Pierzchowiczach pozew od woźnego Michała Jarzembowskiego.

110 Wieś tę niekiedy przyłączano także do Serebryszcz.

111 Poza tym zeznał $\mathrm{z}$ dóbr zastawionych benedyktynkom i Steckiewiczowi abiuraty 1, 1/6 i 2/30 dymów; zob. ML. Podymne nowogrodzkie 1690, s. 141. 
„Libertowanych dymów powiatu słonimskiego” z 25 marca 1714 r. przynosi informację, że opłacił on podatek z Serebryszcz z 15 dymów ${ }^{112}$. Wynikałoby z tego, że jeszcze wtedy był nominalnym właścicielem tamtejszych gruntów. Niedługo potem zmarł. Przyjmując zwyczajowy, co najmniej roczny okres żałoby, musiało to nastąpić najpóźniej do połowy 1716 r., wdowa po nim 10 lipca 1717 r. była już bowiem żoną Dominika Antoniego Bułhaka, podstolego smoleńskiego ${ }^{113}$. $Z$ drugiej strony wiemy, że umarł on przed osiągnięciem lat sprawnych przez syna Jana, urodzonego przed 10 lipca 1697 r. ${ }^{114}$ Tym samym możemy założyć, że zgon Chryzostoma Karpia nastąpił jednak w 1714 r., po 25 marca. Dożył on zatem 64 lat.

Urodzony w zamożnym domu, z matki Sapieżanki, kasztelanki wileńskiej z linii kodeńskiej, na pewno otrzymał należyte wykształcenie i obycie. Dzięki inicjatywie i pomocy ojca Józefa Eliasza Karpia, podkomorzego ziemi bielskiej, w wieku 22 lat został posłem na sejm Rzeczypospolitej (1673 r.). Co prawda źródeł z jego pierwszych 35 lat życia mamy niewiele, ale wszelkie przesłanki mówią, że na tym właśnie zakończyła się jego aktywność publiczna. Możemy jedynie przypuszczać, że czas ten upłynął mu na służbie w chorągwiach siedemnastowiecznej Rzeczypospolitej. Najprawdopodobniej, jak przystało na młodego, bogatego szlachcica, dobrze zapoznał się z rzemiosłem rycerskim. Jednak kariery wojskowej nie zrobił. Nie pełnił również żadnych urzędów ani nie sprawował funkcji publicznych, chociaż dobre urodzenie i oddziedziczony pokaźny majątek (7 dworów) stawiało go niejako a priori w gronie szlachty urzędniczej. Co ciekawe, podobnie pod tym względem potoczyły się także losy jego młodszych braci Krzysztofa Ubalda i Stanisława Antoniego. Wyjątkiem jest tu wprawdzie drugi z kolei Teodor Leon(ard) Karp, rotmistrz JKM, ale ten sięgnął zaledwie po „mizerne” podstolstwo podlaskie. Uposażenie i koligacje rodzinne z pewnością umożliwiały im wszystkim znacznie bardziej imponującą karierę. W sferze gospodarczej nasz bohater także zasługuje na nie najlepszą ocenę. Początkowo dobrze sytuowany właściciel, utracił w ciągu swojego życia znaczną część tych zasobów. Resztę dóbr zaś mocno zadłużył. Prawdopodobnie sprzyjał temu jego rozrzutny styl bycia lub nieumiejętność czy może wręcz kompletny brak zainteresowania gospodarowaniem na roli. Takie podejście dość szybko odbiło się na stanie posiadania rodziny. Jego potomstwo wchodząc $w$ dorosłe życie, pretendowało wspólnie już do raczej marnej spuścizny. Był przedstawicielem szóstego pokolenia rodziny Karpiów herbu własnego i wydaje się, że swoją postawą zaprzepaścił nie tylko jej dorobek materialny, ale dotychczasową pozycję wśród powietników (Podlasie, Grodzieńszczyzna, pow. wołkowyski i słonimski). A trzeba tu przypomnieć,

\footnotetext{
112 NGAB, f. 1737, inw. 1, nr 27, k. 258.

113 LVIA, SA 71, k. 1079-1082v.

114 O latach sprawnych Jana zob. Biblioteka PAN Kraków, sygn. 2444, k. 6-7.
} 
że w gronie ascendentów po mieczu miał dwóch szesnastowiecznych sędziów (Karp Jesypowicz ${ }^{115}$, Iwan ${ }^{116}$ ), wierzyciela królewskiego (Iwan, starostwo nowodworskie pod Ostryną), sekretarza królewskiego i podwojewodziego wileńskiego $\left(\right.$ Dymitr) ${ }^{117}$, dwóch marszałków wołkowyskich (Józef ${ }^{118}$, Stefan Józef ${ }^{119}$ ), dwóch podkomorzych (Mikołaj, wołkowyski i Józef Eliasz, bielski), co najmniej czterech wychowanków dworów królewskiego (Jagiellonów: Iwan ${ }^{120}$, Dymitr; Wazów: Stefan Józef, Józef Eliasz) i przynajmniej sześciu posłów na sejmy (Dymitr, Józef, Józef Eliasz), w tym trzech na sejmy elekcyjne (Stefan Józef, Kazimierz Florian ${ }^{121}$, Józef Eliasz - trzykrotnie). O sukcesach i prestiżu możnych antenatów po kądzieli (Sapiehów) tym bardziej nie wypada tu wspominać. Brak aktywności ze strony naszego bohatera w sferze społeczno-gospodarczo-politycznej miał później również bardzo negatywny wpływ na losy jego bezpośrednich potomków. Już nigdy nie osiągnęli oni pozycji przodków, a jedynymi pełnionymi przez nich urzędami powiatowymi były: oboźny, koniuszy, strażnik i łowczy. Ich status gospodarczy na więcej nie pozwolił. Zresztą nieustannie się pogarszał, podobnie jak ojciec bowiem prowadzili utracjuszowski styl życia.

Z zebranego materiału źródłowego jednoznacznie wynika, że drugą połowę życia Karp strawił na ciągłych procesach sądowych z najbliższymi sąsiadami (Szyszkowie, Jacyniczowie) i - co gorsza - także na krwawych z nimi konfliktach. W te częste utarczki uwikłani byli liczni przedstawiciele tamtejszej (słonimskiej) szlachty. Bez skrupułów wciągano w nie także miejscowych włościan. Tym samym zaprezentowany tu obraz jawi się w ciemnych barwach.

Chryzostom Karp był dwukrotnie żonaty. Z pierwszej małżonki Anny Katarzyny z Ciechanowieckich, podkomorzanki mścisławskiej, miał jedynaka Józefa, który zmarł w wieku młodzieńczym. Z drugiego małżeństwa $\mathrm{z}$ Ewą Teresą

115 S. Karp, Los szesnastowiecznego egzulanta briańskiego na przykładzie Karpia Jesypowicza (ur. ok. 1480 - zm. przed 10 X 1547), „Studia Podlaskie” 23, 2015, s. 7-30.

116 Idem, Iwan Karp (ok. 1535-1591), starosta nowodworski i jego rodzina. Z dziejów szlachty pogranicza polsko-litewskiego w XVI w., „Komunikaty Mazursko-Warmińskie” 3(289), 2015, s. 479-482.

117 Idem, Dymitr Karp (ok. 1560-1621), podwojewodzi wileński. Nota biograficzna, „Komunikaty Mazursko-Warmińskie" 4(282), 2013, s. 757-771.

118 Idem, Józef Karp (ok. 1567-1637)..., s. 7-40.

119 Idem, Gałą́ rodziny Karpiów na Repli i Żłobowszczyźnie..., s. 25-60.

${ }^{120}$ W 1548 r. odnotowany wśród 12 paziów Barbary Radziwiłłówny. 13 VII 1551 r. w Wilnie przyjęty na służbę u Zygmunta Augusta w charakterze pokojowca mniejszego. Od 1 IV 1555 r. dworzanin konny służący w 4 konie. 6 XI 1562 r. wzmiankowany jako dworzanin. Od 11 V do 24 VI 1565 r. posłaniec-lustrator wielkiego księcia litewskiego do oszacowania strat wyrządzonych przez wojsko. Następnie 24 VII 1567 r. w Grodnie u boku marszałka Iwana Wołłowicza wraz ze swoim bliskim kuzynem Iwanem Grigoriewiczem Tryzną Iwan Karp, dworzanin królewski przyjmował poselstwo Iwana Groźnego; szerzej zob. S. Karp, Iwan Karp (ok. 1535-1591)..., s. 479-482.

121 S. Karp, Karty z życia Kazimierza Floriana Karpia (ok. 1628-1656), podstolica podlaskiego, „Studia Łomżyńskie" 29, 2019, s. 161-178. 
Niewiarowską, starościanką kadaryską i maćkowską, wdową po Ferdynandzie Janie Rorze (von Rohr), stolniku trockim, miał czworo dzieci. W chwili zawarcia ponownego małżeństwa był już mężczyzną w zaawansowanym wieku (47 lat). Potomstwo pozostawił niepełnoletnie. $Z$ córek wieku dorosłego dożyła Anna, która została siostrą zakonu św. Franciszka panien bernardynek konwentu słonimskiego, a półroczna dziewczynka nieznanego imienia zmarła 29 czerwca $1702 \mathrm{r}$. w wyniku następstw najazdu Szyszków na dwór w Serebryszczach, płód trzeciej córki zaś żona Ewa Teresa Karpiowa straciła w trakcie ucieczki przed napastnikami ze Świran 17 maja 1702 r. Pełnoletności dożyli natomiast dwaj synowie: Jan i Franciszek. Od nich to właśnie dalej rozgałęziła się rodzina Karpiów na Podlasiu (Karpowicze), w powiecie słonimskim (Iwankowicze, Pierzchowicze), a także na Żmudzi w powiecie rosieńskim, parafii szwekszniańskiej (Szołpiany, Borejkiany) $)^{122}$.

Na zakończenie warto zaznaczyć, że jednym z najbliższych przyjaciół Chryzostoma Karpia był Ignacy Tołokoński, horodniczy brasławski. Później opiekował się on także jego osieroconymi synami.

Ostatnia wzmianka o Ewie Teresie z Niewiarowskich primo voto Ferdynandowej Rorowej, stolnikowej trockiej, secundo voto Chryzostomowej Karpiowej, podkomorzycowej ziemi bielskiej, tertio voto Dominikowej Antoniowej Bułhakowej, podstolinie smoleńskiej, pochodzi z 10 listopada 1729 r. ${ }^{123}$ Postać jej trzeciego męża pozostaje niemal nieznana. Nie odnotowują go ani herbarze, ani nawet monografia rodziny Bułhaków ${ }^{124}$. Wiemy jedynie, że w 1700 r. stawił się $\mathrm{z}$ powiatem słonimskim na popisie pospolitego ruszenia w Olkienikach ${ }^{125}$. Po śmierci Karpiowej ożenił się z Beatą Bychowcówną. Osiadł w dawnych karpiowskich dobrach Wysock Mniejszy; żył jeszcze 21 maja 1739 r. ${ }^{126}$

122 Należy podkreślić, że ze starszą, żmudzką linią rodziny, dziedziczącą Rykijów, a później Lassy, Johaniszkiele, Kursze itd., łączył ich dopiero szesnastowieczny wspólny przodek Iwan Karp (ok. 1535-1591), starosta nowodworski. A zatem możemy rozróżnić dwa etapy migracji członków rodziny Karpiów herbu własnego na Żmudź. Pierwszy pod koniec XVI w. w osobie Mikołaja Karpia, podkomorzego wołkowyskiego, i drugi pod koniec XVIII w. w osobie Józefa Karpia, koniuszyca słonimskiego.

${ }^{123}$ NGAB, f. 1737, inw. 1, nr 29, k. 656v. Była matką 7 dzieci. Co najmniej 3 synów spłodzonych z Ferdynandem Rorem oraz 2 córek i 2 synów ze związku z Chryzostomem Karpiem.

124 W. Bułhak, Buthakowie. Zarys historii rodu, Warszawa 1994.

125 Bitwa rozegrała się 18 XI 1700 r.; zob. Olkieniki - Postanowienie Generalne Stanów W. X. Litewskiego wiecznie y nigdy nie naruszone, na Zjeździe Walnym woiewództw y powiatów, pospolitym ruszeniem pod Olkienikami uchwalone, RP 1700, Wilno 1700.

126 Urzędnicy Wielkiego Księstwa Litewskiego spisy, t. 4: Ziemia smoleńska i województwo smoleńskie, XIV-XVIII wiek, red. A. Rachuba, oprac. H. Lulewicz, A. Rachuba, P.P. Romaniuk, Warszawa 2003, s. 151. 


\section{Streszczenie}

W artykule przedstawiono postać Chryzostoma Karpia (1650-1714), podkomorzyca ziemi bielskiej, posesjonata $\mathrm{z}$ powiatu słonimskiego. Właściciel siedmiu dużych majętności, tracił czas na krwawe spory z sąsiadami i ciągłe procesy sądowe. Ponadto nie interesując się gospodarką w majątkach, doprowadził je do ruiny. W rezultacie stracił ich większą część. Na przykładzie jego życiorysu, a także postaw innych wpływowych przedstawicieli rodzin szlacheckich (Szyszków, Wołk-Łaniewskich, Jacyniczów) ukazano specyfikę zachowań tamtejszej szlachty na przełomie XVII i XVIII w.

\section{In the Shadow of the Debts, Neighbourly Disputes, Forays, and Lawsuits. The Image of Chryzostom Karp (1650-1714), a Landowner from the Slonim County Summary}

The article presents the figure of Chryzostom Karp (1650-1714) a rich landowner from the Slonim County. The owner of seven large estates was wasting time on bloody disputes with neighbours and constant lawsuits. In addition, he was not interested in managing his own properties. As a result, the economy of his estates suffered, and he lost most of them. On the example of his biography as well as the attidudes of other influential representatives of noble families from this area (Szyszko, Wolk-Laniewski, Jacynicz) the specific behaviour of the local nobility at the turn of the eighteenth century was shown.

\section{Bibliografia}

\section{Źródła archiwalne}

Archiwum Narodowe w Krakowie, Zbiór Zygmunta Glogera, sygn. 16.

Lietuvos valstybès istorijos archyvas, Vilnius (LVIA), SA 50, 71, 347, 349, 356, 392, 393, 399, 14805; 4717, t. 2; 4718, t. 1; f. 389, ap. 1, nr 382, cz. 8, nr 505.

Нацыянальны гістарычны архіў Беларусі, Мінск (NGAB), f. 1711, inw. 1, nr 1, 2; f. 1712, inw. 1, nr 3; f. 1737, inw. 1, nr 27, 29; f. 1755, inw. 1, nr 44, 56; f. 1785, inw. 1, nr 45, 46, 47, 48; f. 1839, inw. $1, \mathrm{nr} 2$.

Российский государственный архив древних актов, Москва (RGADA), f. 356, inw. 1, nr 34.

\section{Źródła drukowane}

Jurkowski G., Wonność mistycznej róży, Wilno 1762.

Metryka Litewska. Rejestry podymnego Wielkiego Księstwa Litewskiego. Województwo nowogrodzkie 1690 r., red. A. Rachuba, oprac. H. Lulewicz, A. Rachuba, Warszawa 2002.

Metryka Litewska. Rejestry podymnego Wielkiego Księstwa Litewskiego. Województwo trockie 1690 r., oprac. H. Lulewicz, Warszawa 2000.

Metryka Litewska. Rejestry podymnego Wielkiego Księstwa Litewskiego. Województwo wileńskie 1690 r., oprac. A. Rachuba, Warszawa 1989.

Olkieniki - Postanowienie Generalne Stanów W. X. Litewskiego wiecznie y nigdy nie naruszone, na Zjeździe Walnym woiewództw y powiatów, pospolitym ruszeniem pod Olkienikami uchwalone, RP 1700, Wilno 1700.

Pietruski O., Elektorów poczet, którzy niegdyś głosowali na elektorów Jana Kazimierza roku 1648, Jana III roku 1674, Augusta II roku 1697 i Stanisława Augusta roku 1764, Lwów 1845. 


\section{Opracowania}

Aftanazy R., Dzieje rezydencji na dawnych kresach Rzeczypospolitej, t. 2: Województwo brzesko-litewskie, nowogródzkie, Wrocław 1993.

Boniecki A., Herbarz polski, t. 2, Warszawa 1900.

Borkowska M. OSB, Panny siostry w świecie sarmackim, Warszawa 2002.

Bułhak W., Bułhakowie. Zarys historii rodu, Warszawa 1994.

Deputaci Trybunału Głównego Wielkiego Księstwa Litewskiego 1582-1696. Spis, red. A. Rachuba, oprac. A. Rachuba, H. Lulewicz, Warszawa 2007.

Deputaci Trybunału Głównego Wielkiego Księstwa Litewskiego 1697-1794. Spis, red. A. Rachuba, oprac. A. Rachuba, P.P. Romaniuk, współpr. A. Macuk, J. Aniszczenko, Warszawa 2004.

Dzieje rodziny Ciechanowieckich herbu Dąbrowa (XIV-XXI), red. A. Rachuba, oprac., H. Lulewicz, A. Rachuba, J. Sikorska-Kulesza, S. Dumin, A. Haratym, A. Macuk. A. Pospiszil, Warszawa 2013.

Hundert Z., Konfederacja szczebrzeszyńska 1672-1673 a ziemia bielska, „Przegląd Historyczny” 107, 2016, nr 2, s. 233-245.

Karp S., Crimen w życiu szlachty polskiej. Obraz zatargu sąsiedzkiego w Rzeczypospolitej XVIII w., „Podlaski Kwartalnik Kulturalny” 2011, nr 3, s. 7-19.

Karp S., Dymitr Karp (ok. 1560-1621), podwojewodzi wileński. Nota biograficzna, „Komunikaty Mazursko-Warmińskie" 4(282), 2013, s. 757-771.

Karp S., Gałaź rodziny Karpiów na Repli i Żłobowszczyźnie w XVII w. Studium genealogiczno-majątkowe, „Studia Podlaskie” 27, 2019, s. 25-60.

Karp S., Iwan Karp (ok. 1535-1591), starosta nowodworski i jego rodzina. Z dziejów szlachty pogranicza polsko-litewskiego w XVI w., „Komunikaty Mazursko-Warmińskie” 3(289), 2015, s. 479-482.

Karp S., Jan Karp (1604-1644), podstoli podlaski, życie i działalność, „Studia Podlaskie” 21, 2013, s. 29-49.

Karp S., Józef Karp (ok. 1567-1637), marszałek wołkowyski - rys biograficzny, „Studia Podlaskie” 24, 2016, s. 7-40.

Karp S., Karty z życia Kazimierza Floriana Karpia (ok. 1628-1656), podstolica podlaskiego, „Studia Łomżyńskie" 29, 2019, s. 161-178.

Karp S., Los szesnastowiecznego egzulanta briańskiego na przykładzie Karpia Jesypowicza (ur. ok. 1480 - zm. przed 10 X 1547), „Studia Podlaskie” 23, 2015, s. 7-30.

Meysztowicz A., Karpiowie herbu własnego, Wilno 1906.

Słownik geograficzny Królestwa Polskiego i innych krajów słowiańskich, t. 7, red. B. Chlebowski, W. Walewski, F. Sulimierski, Warszawa 1886.

Urzędnicy Wielkiego Księstwa Litewskiego. Spisy, t. 1: Województwo wileńskie, XIV-XVIII wiek, red. A. Rachuba, oprac. H. Lulewicz, A. Rachuba, P.P. Romaniuk, Warszawa 2004.

Urzędnicy Wielkiego Księstwa Litewskiego spisy, t. 4: Ziemia smoleńska i województwo smoleńskie, XIV-XVIII wiek, red. A. Rachuba, oprac. H. Lulewicz, A. Rachuba, P.P. Romaniuk, Warszawa 2003.

Wierzbicki L.A., O zgodę w Rzeczypospolitej. Zjazd warszawski i sejm pacyfikacyjny 1673 roku, Lublin 2005.

Żychliński T., Złota księga szlachty polskiej, t. 13, Poznań 1891.

Sławomir Karp - mgr ekonomii, heraldyk, niezwiązany z żadnym ośrodkiem naukowym. Zainteresowania badawcze: genealogia i heraldyka kresowych rodzin szlacheckich Rzeczypospolitej Obojga Narodów. E-mail: skarp63@hotmail.com 